\title{
De neutrale strafrechter
}

\author{
Joachim Meese*
}

\section{Inleiding}

Dat een rechter, en zeker een strafrechter, neutraal moet zijn, is de evidentie zelf. De neutraliteit, meestal aangeduid als de onpartijdigheid of niet-vooringenomenheid, van de rechterlijke macht en van de rechters die daarvan deel uitmaken, is immers essentieel voor een rechtstaat en bepalend voor het vertrouwen van de rechtsonderhorige in het gerechtelijk apparaat. Zelfs de minste schijn van partijdigheid is onduldbaar. Niet alleen moet de strafrechter derhalve neutraal zijn, de partijen die voor die strafrechter komen te staan mogen bovendien geen objectief verantwoorde vrees of indruk hebben dat de rechter vooringenomen zou zijn ten aanzien van de te nemen beslissing, of dat hij niet zou kunnen weerstaan aan de druk van buitenaf. De rechter mag zich enkel laten leiden door objectieve argumenten op basis van de middelen die de partijen aanhalen en de rechtsnorm die hij moet toepassen ${ }^{\mathrm{I}}$. Hij moet zich zelfs onafhankelijk opstellen ten aanzien van zichzelf en moet zodoende abstractie maken van zijn eigen levensbeschouwelijke of andere privé-overtuigingen of vooroordelen, wat gesymboliseerd wordt door het dragen van de toga. Uiteraard mag hij geen enkele partij bevoordelen. Hij moet er te allen tijde voor zorgen dat de behandeling van de zaak in alle sereniteit ${ }^{2}$ en kalmte kan geschieden. De rechter moet zich gereserveerd opstellen en mag ook niet 'prejugeren'. Derhalve mag hij zich niet op voorhand uitspreken over de schuld van de verdachte ${ }^{3}$ of doen uitschijnen dat zijn oordeel daarover reeds gevormd is, ${ }^{4}$ over de aard of de zwaarwichtigheid van de feiten, ${ }^{5}$ of over de persoonlijkheid van de verdachte. ${ }^{6} \mathrm{Hij}$ mag ook geen waardeoordeel vellen over de wijze waarop de verdachte zijn verdediging organiseert. Ten slotte moet er nog op worden gewezen dat objectiviteit en neutraliteit geen volstrekt gelijklopende begrippen zijn. Waar de neutrale rechter per definitie

* Prof. dr. Joachim Meese is docent aan de Universiteit Antwerpen en advocaat.

I P. Van Dijk, F. Van Hoof, A. Van Rijn en L. Zwaak (eds.), Theory and Practice of the European Convention on Human Rights, Antwerpen-Oxford, Intersentia, 2006, 6I4.

2 Cf. Cass. 5 augustus 2003, Arr.Cass. $2003,1556$.

3 Zie bijvoorbeeld Cass. 8 mei I996, Arr.Cass. I996, 423 en RW I996-97, Io6I, met noot A. Vandeplas.

4 Bijvoorbeeld door voor te houden dat de stelling van de verdediging volstrekt onverdedigbaar is.

5 Bijvoorbeeld door te gewagen van walgelijke feiten. Door reeds een mening te geven over de zwaarwichtigheid van de feiten, geeft de rechter volgens Kuty impliciet reeds aan dat deze kunnen leiden tot een strenge bestraffing indien ze bewezen worden verklaard (F. Kuty, L'impartialité du juge en procédure pénale. De la confiance décrétée à la confiance justifiée, Brussel, Larcier, 2005, 85). In de praktijk zijn er echter ook rechters die zich op de zitting streng opstellen, maar zich dan mild uitspreken in het vonnis.

6 Zie hierover F. Kuty, L'impartialité du juge en procédure pénale. De la confiance décrétée à la confiance justifiée, Brussel, Larcier, 2005, 85-86. 
objectief zal zijn, is het omgekeerde niet noodzakelijk het geval.7 Een rechter kan zijn functie dus in alle objectiviteit uitoefenen maar toch niet neutraal bevonden worden vanuit het standpunt van de partijen. ${ }^{8}$

In dit preadvies wordt een overzicht gegeven van de waarborgen die in België voorhanden zijn om die zo belangrijke onpartijdigheid van de strafrechter te vrijwaren $^{9}$ en wordt verder aandacht besteed aan enkele mogelijke kwetsbaarheden en bedreigingen op dat vlak. Daarbij is er voor geopteerd om te vertrekken vanuit het - ondertussen klassiek geworden - onderscheid tussen de zogenoemde objectieve (of functionele) onpartijdigheid en de subjectieve (of persoonlijke) onpartijdigheid van de strafrechter. ${ }^{\text {IO }}$ Wel moet gezegd worden dat de scheidingslijn tussen beide vormen van onpartijdigheid niet steeds eenvoudig te trekken valt en het onderscheid trouwens ook in de rechtspraak van het EHRM lijkt te vervagen sedert het arrest Kyprianou. ${ }^{\text {II }}$ Zo kunnen elementen die in dit preadvies beschreven staan onder de instrumenten die bijdragen aan de subjectieve neutraliteit, soms ook worden beschouwd als waarborgen voor de objectieve neutraliteit en omgekeerd. Meestal kiest men trouwens al snel om een regel te catalogiseren onder het objectieve onpartijdigheidsvereiste en niet onder het subjectieve onpartijdigheidsvereiste, zelfs wanneer die regel duidelijk tot doel heeft te vermijden dat de persoon van de rechter partijdig zou zijn, bijvoorbeeld omdat hij rechter zou zijn in eigen zaak. Dat is uiteraard begrijpelijk, omdat het eventuele bewijsproblemen uitsluit. De subjectieve partijdigheid valt nu eenmaal moeilijker aan te tonen dan de objectieve partijdigheid. Zo beschouwd kan men alle instrumenten die in dit preadvies worden besproken, eigenlijk ook catalogiseren onder diegene die de objectieve onpartijdigheid moeten vrijwaren. De onderverdeling die hier wordt gehanteerd, heeft dan ook geenszins de pretentie doctrinair te zijn, doch wordt slechts gehanteerd met het oog op het leesgemak en ter bevordering van de vergelijking tussen de rechtsstelsels van België en Nederland.

Alhoewel de titel van het preadvies het slechts heeft over de neutraliteit van de strafrechter, zijn de begrippen onpartijdigheid en onafhankelijkheid erg nauw

7 F. Kuty, L'impartialité du juge en procédure pénale. De la confiance décrétée à la confiance justifiée, Brussel, Larcier, 2005, 77.

8 Zie met betrekking tot het openbaar ministerie bij het Hof van Cassatie EHRM 30 oktober I99I, Borgers t. België, §26, RW I99I-92, III8, JT I992, I69, JLMB I992, 2, Rev.trim.DH I992, 20I, met noot J. Callewaert en NJB ig92, IIgI.

9 De woorden neutraliteit en onpartijdigheid, die elkaars synoniem zijn, worden in dit preadvies dooreen gebruikt. In de Belgische rechtspraak en rechtsleer wordt evenwel steevast verwezen naar de rechterlijke onpartijdigheid.

Io Dit onderscheid werd door het EHRM voor het eerst gemaakt in een Belgische zaak (EHRM I oktober I982, Piersack t. België, §30: 'a distinction can be drawn in this context between a subjective approach, that is endeavoring to ascertain the personal conviction of a given judge in a given case, and an objective approach, that is determining whether he offered guarantees sufficient to exclude any legitimate doubt in his respect').

II EHRM I5 december 2005, Kyprianou t. Cyprus. Zie hierover A. Ooms, 'De rechterlijke onpartijdigheid is niet steeds wat ze lijkt. Een historische en prospectieve analyse over de grens tussen objectieve en subjectieve onpartijdigheid', CDPK 2010, 499-525. 
verwant: mocht de onafhankelijkheid van de rechterlijke macht niet kunnen worden gegarandeerd, dan zou meteen ook de onpartijdigheid van de (straf)rechter in het gedrang komen. ${ }^{12}$ Onafhankelijkheid duidt op de autonomie van de besluitvorming $^{13}$ en is derhalve een middel om een essentiële waarde, met name de onpartijdigheid van de rechter, veilig te stellen. ${ }^{14}$ Meer nog, het vereiste van onpartijdigheid is de bestaansreden van de rechterlijke onafhankelijkheid. ${ }^{15}$ Niet voor niets worden beide begrippen dus in één adem genoemd in de artikelen 6.I EVRM en I4 IVBPR. Volgens sommigen is de grens tussen beide begrippen zelfs zeer onduidelijk. ${ }^{\mathrm{i}}{ }^{\mathrm{O}} \mathrm{Om}$ die reden wordt in het preadvies, weze het beknopt, toch ook aandacht besteed aan de wijze waarop de onafhankelijkheid van de rechterlijke macht in België wordt gewaarborgd, al moet het gezegd dat over de onafhankelijkheid van de rechter als dusdanig een tiental jaar terug reeds werd gepreadviseerd. ${ }^{17}$

Opnieuw onder verwijzing naar de titel van het preadvies, moet vastgesteld worden dat de te bespreken problematiek de neutraliteit van de strafrechter betreft, en dus niet van de tuchtrechter. Dat aspect wordt dus niet besproken, ook al zijn er met betrekking tot diverse tuchtprocedures best wel vragen te stellen aangaande het vereiste van onpartijdigheid. ${ }^{8}{ }^{8}$

I2 Daarmee is uiteraard niet gezegd dat het waarborgen van de onafhankelijkheid volstaat om ook de onpartijdigheid van de strafrechter te kunnen vrijwaren.

I3 Adams onderscheidt vier vormen van rechterlijke onafhankelijkheid: de individuele onafhankelijkheid van de rechter, de interne onafhankelijkheid (daarmee wordt bedoeld de mate van beïnvloeding van rechters onderling, wat nochtans geen aanleiding geeft tot een schending van het recht op een onafhankelijke rechter als ook die andere rechters onafhankelijk zijn: zie EHRM 4 december 1979, Schiesser t. Zwitserland, \$3I), de buiten-institutionele onafhankelijkheid (de mate van beïnvloeding van buitenaf, bijvoorbeeld door de media) en de institutionele onafhankelijkheid (M. Adams, 'Vrijheid en verantwoordelijkheid van de rechterlijke macht', in X., Verantwoordelijkheid en recht, Mechelen, Kluwer, 2008, nrs. I8-22, I42-I45).

I4 M. Storme, 'Betekenis en statuut van de rechterlijke macht als staatsmacht', TPR I996, I365. Zie in dezelfde zin H. Vandenberghe, 'De onafhankelijkheid van de rechter', in F. Fleerackers en R. Van Ransbeeck (eds.), Recht en onafhankelijkeid. Gerechtelijke macht in perspectief, Brussel, Larcier, 2008, nr. 3, 75 .

I5 G. Delvoie, AJT Dossier I995-96, ro6.

I6 A. Ooms, 'De rechterlijke onpartijdigheid is niet steeds wat ze lijkt. Een historische en prospectieve analyse over de grens tussen objectieve en subjectieve onpartijdigheid', CDPK 20I0, 50I.

I7 P. Van Orshoven, L.F.M. Verhey en K. Wagner, De onafhankelijkheid van de rechter, preadvies voor de Vereniging voor de Vergelijkende Studie van het Recht van België en Nederland, Deventer, Tjeenk Willink, 200I, I2I p.

I8 Zo komt Maffei tot de conclusie dat wat het tuchtrecht voor magistraten betreft een hervorming noodzakelijk is omdat leden van het openbaar ministerie berecht worden door hun hiërarchische overste waardoor er sprake is van een schijn van partijdigheid (P. Maffei, 'Tuchtrecht voor magistraten en EVRM', in F. Deruyck, M. De Swaef, J. Rozie, M. Rozie, Ph. Traest en R. Verstraeten (eds.), De wet voorbij. Liber Amicorum Luc Huybrechts, Antwerpen, Intersentia, 2oro, nrs. 32-34, 270-27I). 


\title{
II Waarborgen voor de neutraliteit van de strafrechter
}

\section{A Instrumenten die bijdragen aan de objectieve neutraliteit}

1

\author{
Overzicht
}

Zoals hoger aangegeven, wordt in dit preadvies zowel aandacht besteed aan instrumenten die de onafhankelijkheid als de onpartijdigheid van de strafrechter waarborgen.

Aan het vereiste van onafhankelijkheid wordt voldaan door het principe van de scheiding der machten, door de wettelijke grondslag van de rechtbanken en de grondwettelijke grondslag voor de hoven, door de wijze en de duur van de benoeming van rechters, door het feit dat rechters enkel uit hun ambt kunnen worden ontzet door een vonnis, door het feit dat de wedde van een rechter bij wet wordt bepaald en doordat zijn ambt onverenigbaar is met vele andere ambten. ${ }^{19}$ Bijkomend kan nog verwezen worden naar de wijze waarop rechters worden geëvalueerd en het feit dat zij in beginsel kunnen bogen op een civielrechtelijke immuniteit. De objectieve onpartijdigheid wordt voornamelijk gewaarborgd door het verbod van cumulatie van rechterlijke ambten. Bijkomend kan gewezen worden op de regels inzake bloed- en aanverwantschap en de collegiale samenstelling van sommige correctionele kamers.

Het belang van de rechterlijke onafhankelijkheid kan moeilijk worden overschat. ${ }^{20}$ Die onafhankelijkheid blijkt ook uit de rechtspraak zelf, nu de rechter kan optreden tegen elk van de drie grondmachten: de uitvoerende macht (Flandria-arrest ${ }^{21}$ ), de rechterlijke macht (Anca-arrest ${ }^{22}$ ) en de wetgevende macht (Ferrara-arrest ${ }^{23}$ ). ${ }^{24}$ Toch is de onafhankelijkheid als zodanig pas in 1998 in de Grondwet verwoord, ${ }^{25}$ maar

I9 R. Verstraeten, Handboek Strafuordering, Antwerpen, Maklu, 2007 (4e ed.), nr. I598, 768.

20 P. Van Orshoven, 'De onafhankelijkheid van de rechter naar Belgisch recht', in P. Van Orshoven, L.F.M. Verhey en K. Wagner, De onafhankelijkheid van de rechter, preadvies voor de Vereniging voor de Vergelijkende Studie van het Recht van België en Nederland, Deventer, Tjeenk Willink, 200I, nr. 9,85 .

21 Cass. 5 november I920, JLMB 2000, 23, met noot C. Panier.

22 Cass. 8 december I994, Arr.Cass. I994, I074, RW I995-96, I80, met noot A. Van Oevelen, R.Cass. I995, I7I, met noot A. Van Oevelen, Verkeersrecht I995, I08, JLMB I995, 387, met noot D. Philippe en JT 1995, 497, met noot.

23 Cass. 28 september 2006, RW 2006-07, 27, met noot A. Van Oevelen, TBP 2007, 546, met noot E. Maes, P\&B 2007, 98, JT 2006, 594, JLMB 2006, I548, met noot M. Uyttendaele, NJW 2007, 319, met noot I. Boone, Pas. 2006, I870, CDPK 2007, 218, met noot M. Rigaux, RABG 2007, I99, RABG 2007, 320, met noot C. Verbruggen, RCJB 2007, 353, met noot S. Van Drooghenbroeck en Rev. not.b. 2006, 648, met noot D. Sterckx.

24 M. Storme, 'Onafhankelijkheid van de rechterlijke macht', in F. Fleerackers en R. Van Ransbeeck (eds.), Recht en onafhankelijkheid. Gerechtelijke macht in perspectief, Brussel, Larcier, 2008, nr. 3, 20.

25 Art. I5I GW bepaalt sedertdien dat rechters onafhankelijk zijn in de uitoefening van hun rechtsprekende bevoegdheden. Zie over de draagwijdte van deze bepaling onder meer P. Van Orshoven, 'De onafhankelijkheid van de rechter naar Belgisch recht', in P. Van Orshoven, L.F.M. 
de onafhankelijkheid en onpartijdigheid van de rechter is uiteraard een regel die van oudsher bestaat, ook al was het ongeschreven, en als algemeen rechtsbeginsel werd erkend door de verschillende hogere rechtscolleges. ${ }^{26}$ Bovendien zijn er uiteraard ook de eisen van onafhankelijkheid en onpartijdigheid die voortvloeien uit de artikelen 6.I EVRM en I4.I IVBPR, die directe werking hebben in België. ${ }^{27}$

\subsection{De benoeming voor het leven, de onafzetbaarheid en de onverplaatsbaarheid}

Een uitermate belangrijk element om de volstrekte onafhankelijkheid van de rechterlijke macht te kunnen garanderen, is dat rechters voor het leven worden benoemd en onafzetbaar en onverplaatsbaar zijn. ${ }^{28}$ Ze kunnen weliswaar wel uit hun ambt worden ontzet of geschorst, maar daartoe kan enkel bij vonnis worden beslist, waarbij derhalve noch de Koning noch de wetgevende macht kan tussenkomen. ${ }^{29}$ De onverplaatsbaarheid betekent dat een rechter slechts kan overgeplaatst worden door een nieuwe benoeming en met zijn toestemming. ${ }^{\circ}$ De wedden van de leden van de rechterlijke orde worden door de wet vastgelegd, ${ }^{35}$ wat opnieuw de onafhankelijkheid van de rechterlijke macht ten aanzien van de uitvoerende macht benadrukt. ${ }^{32}$

In tijden waarin crisissen zich opstapelen, bedrijven moeten saneren en zelfs overheden het meer dan moeilijk krijgen om de eindjes aan elkaar te knopen, moet

Verhey en K. Wagner, De onafhankelijkheid van de rechter, preadvies voor de Vereniging voor de Vergelijkende Studie van het Recht van België en Nederland, Deventer, Tjeenk Willink, 200I, nr. I4, 90-9I en J. Velaers, 'De onafhankelijkheid van de rechterlijke macht na de recente herziening van de Grondwet', Limb.Rechtsl. 2000, 373-400.

26 Zowel door het Hof van Cassatie (zie bijvoorbeeld Cass. 26 september I986, Arr.Cass. I986-87, II9), het Grondwettelijk Hof (zie bijvoorbeeld Arbitragehof 2I oktober I998, nr. I07/98) en de Raad van State (zie bijvoorbeeld R.v.St. 2I maart 1992, nr. 39.I34, Arr.R.v.St. I992, 8).

27 Zie hierover onder meer K. Wagner, 'De onafhankelijkheid van de rechter naar Europees recht', in P. Van Orshoven, L.F.M. Verhey en K. Wagner, De onafhankelijkheid van de rechter, preadvies voor de Vereniging voor de Vergelijkende Studie van het Recht van België en Nederland, Deventer, Tjeenk Willink, 200I, I-I8.

28 Art. I52 GW.

29 Zie over de tuchtwetgeving voor magistraten onder meer J. Van Compernolle en M. Storme (eds.), Het tuchtrecht voor magistraten, Antwerpen, Kluwer, 200I, I78 p.; G. Closset-Marchal, 'Tuchtrecht van de magistraten: nota gericht aan de Heer minister van Justitie', RW 200I-02, 68-7I; X. De Riemaecker, 'Aspects du nouveau droit disciplinaire des magistrats', in X., Imperat Lex. Liber Amicorum Pierre Marchal, Gent, Larcier, 2003, 309-325; J. Laenens en S. Raes, Justitie hervormd, Antwerpen, Maklu, 2000, I67-I98; Ch. Matray, 'Le nouveau régime disciplinaire des magistrats. Arcanes et dédales de procédure', JT 2000, I33-I45; J. Matray, 'Le nouveau régime disciplinaire des magistrats de l'ordre judiciaire', Act.dr. 200I, 39-6I en P. Maffei, 'Tuchtrecht voor magistraten en EVRM', in F. Deruyck, M. De Swaef, J. Rozie, M. Rozie, Ph. Traest en R. Verstraeten (eds.), De wet voorbij. Liber Amicorum Luc Huybrechts, Antwerpen, Intersentia, 2010, 259-272. Het tuchtsysteem werd reeds geëvalueerd door de Hoge Raad voor de Justitie, die in een advies van 25 november 2009 een voorstel tot aanpassing van het tuchtrecht voor de rechterlijke orde heeft uitgewerkt (dit advies kan geraadpleegd worden via volgende link: www.csj.be/doc/advice/avis26riog.pdf).

30 Wel bestaan er toegevoegde rechters die worden benoemd per rechtsgebied die hun ambt tijdelijk bij een bepaalde rechtbank in het rechtsgebied uitoefenen (art. 86bis Ger.W.). Rechters kunnen ook aangewezen worden om tijdelijk het ambt waar te nemen in een andere rechtbank van het rechtsgebied, doch ook in dat geval is zulks enkel mogelijk met instemming van de betrokken rechter (zie art. 98 Ger.W.).

3 Art. I54 GW.

32 J. Laenens, K. Broeckx, D. Scheers en P. Thiriar, Handboek gerechtelijk recht, Antwerpen, Intersentia, 2008, nr. 355, I95. 
er ongetwijfeld een deugdzame zekerheid uitgaan van de rustige vastheid die gepaard gaat met de garantie van een levenslange benoeming. Dat systeem is echter gerechtvaardigd, omdat beslissingen maar in volle onafhankelijkheid kunnen worden genomen als de inhoud van die beslissingen op geen enkele wijze impact kan hebben op de persoon van de beslisser zelf. Ook al wordt de benoeming voor het leven van rechters soms al eens als nadelig voor de kwaliteit van de rechtspraak beschouwd, 33 toch bestaat er geen alternatief dat evenveel waarborgen kan bieden voor de onafhankelijkheid van de rechter. Processen zoals de Fortis-zaak hebben aangetoond dat het van het grootste belang is dat rechters in volstrekte onafhankelijkheid kunnen werken. Hoe kan immers een volstrekte neutraliteit verwacht worden van een rechter die bijvoorbeeld te oordelen heeft over een geschil waarbij de overheid zelf rechtstreeks belanghebbende partij is, als hij weet dat hij nadien misschien kan afgerekend worden op de inhoud van zijn beslissing? ${ }^{34}$ In strafzaken worden in de media af en toe beslissingen geviseerd (soms zelfs met vermelding van de naam en/of afbeelding van de persoon van de rechter) die bijvoorbeeld te mild zouden zijn. Het is geruststellend te weten dat de betrokken rechter zijn of haar toekomstige beslissingen hierdoor niet moet laten beïnvloeden, omdat de inhoud van die beslissingen toch op generlei wijze een invloed kan hebben op de eigen beroepsmatige toekomst. Er wordt dan ook terecht gezegd dat het beginsel van de onafzetbaarheid een hoeksteen vormt voor de onafhankelijkheid van de rechterlijke macht en daarmee een waarborg omvat voor de rechtsonderhorige. ${ }^{35}$ Toch moet erop gewezen worden dat een levenslang mandaat niet vereist wordt door het EHRM. ${ }^{36}$ Dat is ook voor België van belang omdat niet alle sancties waarop het EVRM van toepassing is, worden opgelegd door rechters die voor het leven benoemd zijn. ${ }^{37}$ Wat echter wel vereist is, is dat rechters niet kunnen geconfronteerd worden met een willekeurige afzetting tijdens hun mandaat. ${ }^{8}$ Een veralgemening van het gebruik

33 In die zin W. Van Steenbrugge, De affaire justitie. Bedenkingen van een strafpleiter, Antwerpen, Meulenhof-Manteau, 2007, 98.

34 In uitzonderlijke gevallen kan een rechter toch nog mede afgerekend worden op de inhoud van zijn beslissingen uit het verleden, met name wanneer hij een voordracht van de Staat nodig heeft omdat hij een bepaalde functie ambieert. Zo was er recent een en ander te doen rond het feit dat België niemand zal voordragen voor het IRMCT (International Residual Mechanism for Criminal Tribunals), terwijl raadsheer Delvoie (ironisch genoeg ook de auteur van een artikel over de onafhankelijkheid van de rechter: AJT Dossier I995-96, Io6-III), die mee beslist had in de Fortis-zaak, nochtans wel kandidaat was. Het valt evenwel niet te achterhalen in welke mate de inhoud van de bewuste beslissing in de Fortis-zaak daarbij heeft meegespeeld.

35 X. De Riemaecker en G. Londers, 'De plaats van de rechterlijke macht in de Staat en zijn logisch gevolg: de onafhankelijkheid van de magistraat', in X., Statuut en deontologie van de magistraat, Brugge, Die Keure, 2000, 32.

36 Zie EHRM r6 juli I97I, Ringeisen t. Oostenrijk, Serie A, vol. I3, §95.

37 Zie bijvoorbeeld met betrekking tot een tuchtsanctie opgelegd door een instantie waarvan de leden benoemd zijn voor een periode van zes jaar EHRM 23 juni I98I, Lecompte, Van Leuven \& De Meyere t. België, Serie A, vol. 43. Zie ook EHRM 28 juni ig84, Campbell \& Fell t. Verenigd Koninkrijk, Serie A, vol. 8o.

38 Zie hierover K. Wagner, 'De onafhankelijkheid van de rechter naar Europees recht', in P. Van Orshoven, L.F.M. Verhey en K. Wagner, De onafhankelijkheid van de rechter, preadvies voor de Vereniging voor de Vergelijkende Studie van het Recht van België en Nederland, Deventer, Tjeenk Willink, 20oI, nr. 5, 7-8. Zo volstaat het bestaan van de mogelijkheid voor een minister om een rechterlijk mandaat naar believen te beëindigen om de schijn van afhankelijkheid te wekken, 
van tijdelijke mandaten zou echter verhinderen dat het magistratenkorps ook rechters bevat die kunnen bogen op een jarenlange ervaring, wat een aspect kan zijn om de kwaliteit van beroepsprocedures te kunnen garanderen. Tijdelijke mandaten zijn immers vooral geen probleem op vlak van onafhankelijkheid als ze niet verlengd kunnen worden. Van zodra tijdelijke mandaten verlengbaar zijn, bijvoorbeeld door herverkiezing of herbenoeming, rijst meteen ook het probleem dat die beslissing ingegeven zou kunnen zijn door de eerdere rechterlijke uitspraken.

\subsection{De benoemingsprocedure}

De wijze waarop rechters (en magistraten in het algemeen) worden benoemd, is in België grondig gewijzigd ingevolge de grondwetsherziening van 20 november 1998 en de wijziging van het Gerechtelijk Wetboek bij wet van 22 december 1998.39 De bedoeling van deze belangrijke aanpassing was om te komen tot een objectivering en depolitisering van de benoemingswijze van magistraten. In het verleden legde de Grondwet de bevoegdheid om magistraten te benomen zonder meer bij de Koning, wat er in de praktijk op neerkwam dat de benoeming geschiedde door de minister van Justitie..$^{\circ}$ De minister van Justitie kon in beginsel vrijelijk kiezen uit de kandidaten die aan de benoemingsvoorwaarden voldeden, dit op grond van een hem eigen opportuniteitsbeoordeling. ${ }^{4 \mathrm{I}}$ De benoeming diende dan ook te worden gezien als een politieke daad waarvoor de minister van Justitie alleen verantwoording verschuldigd was aan het parlement. Dat betekende echter niet dat de minister van Justitie alle beslissingen over benoemingen van magistraten zelf nam: het zwaartepunt van de benoemingspolitiek werd immers verschoven naar de verschillende partijcenakels en een aantal informele commissies, waar dan aan de hand van een eerder ingewikkelde politieke dosering de benoemingen in de magistratuur werden verdeeld onder de belangrijkste politieke families..$^{42}$

Een eerste belangrijke stap naar de objectivering van de magistratuur werd genomen met de wet van I8 juli I99I, ${ }^{43}$ die onder meer voorzag in de oprichting van het wervingscollege der magistraten en de oprichting van adviescomités. Toch kon daarmee nog niet gesproken worden over een echte depolitisering van de magistratuur, omdat het advies van de adviescomités niet bindend was voor de minister van Justitie, zodat deze nog steeds over een keuzevrijheid beschikte als verschil-

zelfs wanneer van die mogelijkheid in de praktijk slechts zelden gebruik wordt gemaakt (EHRM 22 november 1995, Bryan t. Verenigd Koninkrijk, Serie A, vol. 225-A, §36).

39 Wet van 22 december 1998 tot wijziging van sommige bepalingen van deel II van het Gerechtelijk Wetboek met betrekking tot de Hoge Raad voor de Justitie, de benoeming en aanwijzing van magistraten en tot invoering van een evaluatiesysteem, BS 2 februari 1999.

40 Bij een aantal benoemingen kon de minister van Justitie evenwel niet alleen optreden (zie in dat verband art. 197 Ger.W.).

4I X. De Riemaecker en G. Londers, 'Toegang tot de magistratuur en de loopbaan binnen de magistratuur', in X., Statuut en deontologie van de magistraat, Brugge, Die Keure, 2000, 62.

42 Ibid.

43 Wet van I8 juli I99I tot wijziging van de voorschriften van het Gerechtelijk Wetboek die betrekking hebben op de opleiding en de werving van magistraten, BS 26 juli r99I. Deze wet werd nadien nog op een aantal punten gewijzigd, onder andere door de wet van I december 1994 betreffende de opleiding en werving van magistraten (BS 6 december I994). 
lende kandidaten die aan de wettelijke voorwaarden voldeden postuleerden voor een vacante betrekking. Ook bij bevorderingen was trouwens nog steeds politieke tussenkomst mogelijk. Misschien zou het daarbij gebleven zijn, ware het niet dat er naar aanleiding van de zaak Dutroux (en de daaropvolgende Witte Mars en de werkzaamheden van de parlementaire onderzoekscommissie) dermate veel kritiek kwam op de werking van het gerecht dat een verdere hervorming zich opdrong. Om de objectivering en depolitisering van de magistratuur te bewerkstelligen, werd beslist tot de oprichting van de Hoge Raad voor de Justitie. De Hoge Raad voor de Justitie is een gedepolitiseerde federale instelling met duidelijke taalpariteit en volledige gelijkwaardigheid tussen de magistraten en de niet-magistraten die er deel van uitmaken. ${ }^{44}$ Het betreft een instelling met een sui generis-statuut ${ }^{45}$ die derhalve geen deel uitmaakt van de drie staatsmachten. Sedert de oprichting van de Hoge Raad voor de Justitie, worden magistraten benoemd op gemotiveerde voordracht van de bevoegde benoemings- en aanwijzingscommissie, die bij een tweederdemeerderheid over deze voordracht beslist, overeenkomstig de modaliteiten bij wet bepaald ${ }^{46}$ en na afweging van de bekwaamheid en de geschiktheid van de kandidaten. ${ }^{47}$ De Koning kan vervolgens enkel de door de Hoge Raad voor de Justitie voorgedragen kandidaat benoemen. ${ }^{4}{ }^{3}$ Het komt de Koning niet toe zijn mening aangaande de bekwaamheid en de geschiktheid van de voorgedragen kandidaat in de plaats te stellen van de benoemingscommissie. ${ }^{49}$ Weigert hij te benoemen, dan volgt een nieuwe voordracht. ${ }^{\circ}$ Heeft de benoemings- en aanwijzingscommissie zelf geen kandidaat voorgedragen, dan komt er een nieuwe oproep tot kandidaten.

Het spreekt voor zich dat een geobjectiveerde en gepolitiseerde benoemingsprocedure een belangrijke factor is om de neutraliteit (en in elk geval de perceptie daarvan bij de rechtsonderhorige) van de (straf)rechter in grotere mate te kunnen waarborgen. Ook al werden de politieke benoemingen in het verleden vrij regelmatig verdedigd, uiteindelijk werd toch terecht geconcludeerd dat het gedurende jaren doorgedreven en volgehouden systeem van politieke benoemingen nefast is geweest voor het imago van justitie, doordat minstens naar de burger toe de kwalijke indruk

44 Zowel het Nederlandstalig als het Franstalig college is samengesteld uit elf magistraten van de zetel en van het openbaar ministerie en elf niet-magistraten. Die laatste groep telt per college ten minste vier leden van elk geslacht en bestaat ten minste uit vier advocaten, drie hoogleraren en vier personen met een relevante beroepservaring van ten minste tien jaar (zie art. 259bis-I \$3 Ger. W.). De magistraten worden rechtstreeks verkozen door hun collega's magistraten, terwijl de niet-magistraten met een tweederdemeerderheid worden benoemd door de Senaat.

P. Van Orshoven, 'De staatsrechtelijke positie van de Hoge Raad voor de Justitie', in J. Laenens en M. Storme (eds.), In de ban van Octopus, Antwerpen, Kluwer, 2000, nr. I3, I4.

46 Zie art. 259ter Ger. W.

47 Art. I5I \$4 GW.

48 R.v.St. I6 augustus 200I, JT 200I, 827. Uiteraard moet deze kandidaat wel aan de wettelijke benoemingsvoorwaarden voldoen (J. Laenens en S. Raes, Justitie hervormd, Antwerpen, Maklu, 2000, 36-339, inzonderheid nrs. 58-68).

49 R.v.St. 2I januari 2002, RW 200I-02, I606, met noot I. Opdebeek.

50 J. Laenens, K. Broeckx, D. Scheers en P. Thiriar, Handboek gerechtelijk recht, Antwerpen, Intersentia, 2008, nr. 342, I90. 
werd gewekt dat de magistraat onderworpen is aan de politieke machthebbers. ${ }^{\text {I }}$ Partijpolitieke benoemingen brengen de perceptie van onafhankelijkheid en onpartijdigheid van de magistratuur in het gedrang, ook al neemt de magistraat na zijn benoeming dadelijk en duidelijk afstand van de politieke groeperingen of personen die mede zijn of haar benoeming mogelijk hebben gemaakt.

Volledigheidshalve kan er nog worden aan toegevoegd dat de Hoge Raad voor de Justitie verder nog een belangrijke rol te vervullen heeft bij de aanwijzing in tijdelijke mandaten (waaronder de mandaten van korpschef).

\subsection{De evaluatie van magistraten}

Magistraten worden weliswaar geëvalueerd,,$^{52}$ doch die evaluatie mag enkel slaan op de wijze van ambtsuitoefening van de magistraat, met uitsluiting van de inhoud van de rechterlijke beslissingen die door die magistraat werden genomen.53 Meer in het bijzonder is bepaald dat de evaluatie enkel betrekking heeft op de persoonlijkheid en de intellectuele, professionele en organisatorische capaciteiten. ${ }^{54}$ De evaluatie van magistraten kan derhalve de onafhankelijkheid van de rechter niet in het gedrang brengen.

\subsection{Nevenfuncties}

Sommige rechters oefenen ook nog een of meer nevenfuncties uit, waarbij de vraag kan rijzen of dat aanleiding kan geven tot afhankelijkheid of tot een aantasting van de onpartijdigheid. ${ }^{55}$ Teneinde de onafhankelijkheid van de rechter te vrijwaren, is in België bepaald dat de rechter van de regering geen bezoldigde ambten mag aanvaarden, ${ }^{56}$ noch kan hij voor enige andere openbare dienst worden opgevorderd, ${ }^{57}$ behoudens de aan rechters opgelegde kiesverrichtingen. Onverminderd de onverenigbaarheden die bij wet zijn voorzien, kan de rechter ze wel onbezoldigd uitoefenen..$^{8}$ De ambten van de rechterlijke orde (en van het openbaar ministerie) zijn verder nog onverenigbaar met de uitoefening van een bij verkiezing verleend openbaar mandaat, met enige bezoldigde openbare functie of openbaar ambt van politieke of administratieve aard, met het ambt van notaris of gerechtsdeurwaarder, met het

$5 \mathrm{I}$ X. De Riemaecker en G. Londers, 'Toegang tot de magistratuur en de loopbaan binnen de magistratuur', in X., Statuut en deontologie van de magistraat, Brugge, Die Keure, 2000, 63.

52 Zie art. I5I \$6 GW; ook de werklast van de magistraten moet geregistreerd en geëvalueerd worden (art. 352 bis Ger.W).

53 J. Laenens, K. Broeckx, D. Scheers en P. Thiriar, Handboek gerechtelijk recht, Antwerpen, Intersentia, 2008, nr. 35I, I94.

54 Art. 259nonies, 4e lid Ger.W.

55 Zie over de cumulatie van de rechterlijke functie met de functie als advocaat, professor, militair, syndicalist en parlementslid F. Tulkens en S. Van Drooghenbroeck, 'La double vie du juge est-elle compatible avec son impartialité?', in X., Liber Amicorum Paul Martens. L'humanisme dans la résolution des conflits. Utopie ou réalité?, Brussel, Larcier, 2007, 485-509.

56 Art. $155 \mathrm{GW}$.

57 Art. 296 Ger.W.

58 J. Laenens, K. Broeckx, D. Scheers en P. Thiriar, Handboek gerechtelijk recht, Antwerpen, Intersentia, 2008, nr. 356, I96. 
beroep van advocaat, met de militaire stand en met de geestelijke stand. ${ }^{59}$ De leden van de hoven, rechtbanken, parketten en griffies kunnen niet tegen bezoldiging in een scheidsgerecht optreden ${ }^{60}$ en mogen evenmin de verdediging van partijen voeren of hun consult geven. ${ }^{6 \mathrm{r}}$ Verder is het ook uitgesloten dat zij enige handelsactiviteit zouden uitoefenen, ${ }^{62}$ behalve dan voor wat betreft de plaatsvervangende rechters en raadsheren, de raadsheren en rechters in sociale zaken en de rechters in handelszaken. ${ }^{63}$

Het bekleden van een onderwijsambt is wel mogelijk met machtiging van de Koning en op voordracht van de minister van Justitie. ${ }^{64}$ Ook het vervullen van opdrachten bij internationale, supranationale of buitenlandse instellingen is mogelijk mits machtiging. ${ }^{6}$ Hetzelfde geldt voor de deelneming aan een commissie, een raad of comité van advies of, krachtens een bijzondere opdracht, aan het beheer of het toezicht op een openbare instelling. ${ }^{66}$ In dat laatste geval geldt wel een beperking van het aantal bezoldigde opdrachten of ambten tot twee en een maximum van de hierdoor verkregen bezoldiging tot een tiende van de jaarlijkse brutowedde als magistraat. Ten aanzien van de assessoren in strafuitvoeringszaken is voorzien dat een benoeming of een contractuele aanwerving in een bezoldigde openbare functie of ambt van administratieve aard niet uitgesloten is. Ook voor de plaatsvervangende assessoren in strafuitvoeringszaken geldt een uitzondering, in die zin dat zij beroepswerkzaamheden kunnen uitoefenen die voor het opdoen van ervaring toegestaan zijn om te benoemd te worden tot assessor. ${ }^{67}$

Voor het overige bestaat er geen exhaustieve wettelijke regeling die aan de leden van de rechterlijke macht een maximum oplegt qua inkomen uit nevenbetrekkingen. ${ }^{68}$ Er bestaat ook geen wettelijke regeling voor de publicatie van nevenfuncties voor leden van de rechterlijke macht, daar waar een dergelijke verplichting wel bestaat ten aanzien van de wetgevende en uitvoerende macht. ${ }^{69}$

\subsection{De civielrechtelijke immuniteit van magistraten}

De onafhankelijkheid van de rechterlijke macht wordt verder gewaarborgd doordat magistraten een volstrekte civielrechtelijke immuniteit genieten van fouten begaan

59 Art. 293 Ger.W.

60 Art. 298 Ger.W.

6I Art. 297 Ger.W.

62 Art. 299 Ger.W.

63 Art. $300, \mathrm{I}^{\mathrm{e}}$ en $2^{\mathrm{e}}$ lid Ger.W.

64 Art. 294, $\mathrm{I}^{\mathrm{e}}$ lid Ger.W.

65 Art. 308 Ger.W.

66 Art. 294, $2^{\mathrm{e}}$ lid Ger.W.

67 Zie art. $300,3^{\mathrm{e}}$ en $4^{\mathrm{e}}$ lid Ger.W.

68 M. Sterkens, 'Een transparant en onpartijdig rechter', in F. Deruyck, M. De Swaef, J. Rozie, M. Rozie, Ph. Traest en R. Verstraeten (eds.), De wet voorbij. Liber Amicorum Luc Huybrechts, Antwerpen, Intersentia, 2010, 374 .

69 Zie hierover M. Sterkens, 'Een transparant en onpartijdig rechter', in F. Deruyck, M. De Swaef, J. Rozie, M. Rozie, Ph. Traest en R. Verstraeten (eds.), De wet voorbij. Liber Amicorum Luc Huybrechts, Antwerpen, Intersentia, 2010, 375-376. 
in de uitoefening van hun ambt, $7^{70}$ behoudens voor wat betreft een aantal limitatief opgesomde ambtsfouten die wel tot persoonlijke burgerrechtelijke aansprakelijkheid van de magistraat kan leiden. ${ }^{7 \mathrm{I}}$ Wordt er voor het overige schade veroorzaakt door een fout begaan door een rechter (of een magistraat van het openbaar ministerie) in de uitoefening van zijn ambt, dan is de Belgische Staat daarvoor verantwoordelijk..$^{22}$ De fout die kan leiden tot aansprakelijkheid van de Staat, bestaat in de regel in een gedraging die ofwel neerkomt op een verkeerd optreden dat moet worden beoordeeld naar de maatstaf van een normaal zorgvuldige en omzichtige magistraat die in dezelfde omstandigheden verkeert, ofwel - behoudens onoverkomelijke dwaling of enige andere rechtvaardigingsgrond - in een schending van een nationaalrechtelijke norm of een internationaal verdrag met rechtstreekse werking in de interne rechtsorde die de magistraat oplegt zich van een handeling te onthouden of op een bepaalde wijze te handelen.73 Die aansprakelijkheid is niet onverenigbaar met de onafhankelijkheid van de rechterlijke macht, aangezien die onafhankelijkheid voldoende gewaarborgd is door de wettelijke onmogelijkheid om magistraten persoonlijk aansprakelijk te stellen buiten de gevallen waarin zij strafrechtelijk veroordeeld zijn en de gevallen waarin verhaal op de rechter mogelijk is. ${ }^{74}$

3 Het verbod van cumulatie van rechterlijke ambten

Het staat buiten kijf dat een van de belangrijkste elementen om de objectieve neutraliteit van de (straf)rechter te kunnen waarborgen, bestaat uit het verbod van cumulatie van rechterlijke ambten. ${ }^{75}$ Binnen het bestek van dit preadvies kan evenwel geen volledige bespreking worden gegeven van dat verbod, ${ }^{76}$ maar kunnen slechts enkele krachtlijnen worden overlopen.

Wat de rechtsgrond betreft, kan in het interne recht verwezen worden naar artikel 292 van het Gerechtelijk Wetboek, dat zowel de gelijktijdige als de achtereenvolgende

70 Zie bijv. Brussel 2I november I989, JT I990, 759.

7 I Art. II40 Ger.W. somt volgende gevallen op: indien de magistraat zich aan bedrog of list heeft schuldig gemaakt tijdens het onderzoek of bij zijn vonnis, indien verhaal op de rechter uitdrukkelijk bij wet is bepaald, indien de wet de rechter aansprakelijk stelt voor eventuele schade en indien rechtsweigering is geschied.

72 Cass. I9 december I99I, Arr.Cass. I99I-92, 364, R.Cass. I992, 3, met noot A. Van Oevelen, RW I99293, 396, met noot, RRD 1992, 4II, met noot C. Jassogne, JT 1992, I42, Journ.Proc. I992, 20, met noot C. Panier, JLMB I992, 42, met noot F. Piedboeuf en RCJB I993, 285, met noot F. Rigaux en J. Van Compernolle. Zie ook M. Storme, 'Sancties wegens een ontoegankelijk gerecht', in X., Mélanges J. Van Compernolle, Brussel, Bruylant, 2004, 633-650.

73 Cass. 8 december 1994, Arr.Cass. 1994, I074, RW 1995-96, I80, met noot A. Van Oevelen, R.Cass. I995, I7I, met noot A. Van Oevelen, Verkeersrecht I995, I08, JLMB I995, 387, met noot D. Philippe en JT I995, 497, met noot.

74 J. Laenens, K. Broeckx, D. Scheers en P. Thiriar, Handboek gerechtelijk recht, Antwerpen, Intersentia, 2008, nr. 365, 199-200.

75 In die zin ook M.I. Veldt, Het EVRM en de onpartijdige strafrechter, Deventer, Gouda Quint, I997, 384.

76 Zie voor een zeer uitgebreide en volledige analyse van het verbod van cumulatie van rechterlijke ambten echter F. Kuty, L'impartialité du juge en procédure pénale. De la confiance décrétée à la confiance justifiée, Brussel, Larcier, 2005, 29I-586. 
cumulatie verbiedt ${ }^{77}$ en van openbare orde is. ${ }^{78}$ Specifiek met betrekking tot het hof van assisen, is er bovendien nog artikel 127 van hetzelfde wetboek. ${ }^{79}$ In strafzaken is het verbod van cumulatie echter veel ruimer dan datgene dat artikel 292 van het Gerechtelijk Wetboek omvat, omdat die bepaling op een strikte wijze wordt toegepast en aldus enkel het verbod inhoudt dat een rechter kennis zou nemen van een zaak in eerste en tweede aanleg, ${ }^{80}$ iets wat overigens ook een wrakingsgrond oplevert. ${ }^{8 \mathrm{r}}$ Die ruimere invulling is onder meer gesteund op het algemeen rechtsbeginsel van het recht op een onafhankelijke en onpartijdige rechter ${ }^{82}$ en op de artikelen 6.I EVRM en I4.I IVBPR. Op grond hiervan wordt geen enkele uitwendige schijn aanvaard dat de rechter partijdig zou zijn, dit los van de persoonlijke overtuiging van de betrokken rechter. Van een dergelijke schijn van partijdigheid kan sprake zijn doordat de rechter die moet oordelen over een zaak, vroeger al eens in een andere hoedanigheid heeft kennisgenomen van die zaak. ${ }^{83} \mathrm{Nu}$ zijn er in strafzaken heel

77 Art. 292 Ger.W. bepaalt dat cumulatie van rechterlijke ambten verboden is (zo kan men bijvoorbeeld niet tegelijkertijd rechter zijn bij de rechtbank van eerste aanleg en raadsheer in het hof van beroep), uitgenomen de gevallen die de wet bepaalt (eerste lid) en dat nietig is het vonnis, gewezen door een rechter die vroeger bij het uitoefenen van een ander rechterlijk ambt kennis genomen heeft van de zaak (tweede lid).

78 Cass. 29 november 1996, Arr.Cass. 1996, nr. 469, Cass. io maart 1997, Arr.Cass. I997, nr. I34 en Cass. Io april 2003, Arr.Cass. 2003, nr. 243.

79 Deze bepaling luidt als volgt: 'Op straffe van nietigheid mogen de magistraten die als onderzoeksrechter of openbaar ministerie zijn opgetreden of uitspraak hebben gedaan over de regeling van het onderzoek, de assisen niet voorzitten noch als assessor optreden, en de personen die in de zaak opdrachten van gerechtelijke politie hebben vervuld of deel hebben genomen aan een daad van ambtelijk onderzoek of van strafonderzoek, en diegenen die getuige, deskundige, tolk, aangever, klager of betrokken partij zijn geweest, mogen geen gezworene zijn'.

80 R. Verstraeten, Handboek Strafvordering, Antwerpen, Maklu, 2007 (4e ed.), nr. I6I8, 780. Op basis van deze bepaling mag een rechter geen kennis meer nemen van een zaak in graad van beroep waarin hij reeds als onderzoeksrechter is tussengekomen (Cass. I8 maart I98I, Arr.Cass. I980-8I, 789, RW I980-8I, 2533 en Rev.dr.pén. I98I, 703; Cass. 2I oktober 1987, Arr.Cass. I987-88, nr. I04), tenzij hij als onderzoeksrechter enkel de klacht met burgerlijke partijstelling heeft ontvangen maar het onderzoek door een andere onderzoeksrechter werd gevoerd (Cass. 25 mei ig88, Arr. Cass. I987-88, nr. 588) of tenzij de eerdere onderzoeksrechter later in het appelgerecht enkel zitting neemt om de zaak uit te stellen zonder uitspraak te doen over de grond van de zaak (Cass. 9 mei 1979, Arr.Cass. 1978-79, I077 en Cass. 2 oktober 200I, Arr.Cass. 200I, nr. 5 II en RW 2003-04, 2I3, met noot A. Vandeplas). Ook het geval van de voorzitter van de raadkamer die een zaak verwezen had naar de politierechtbank en vervolgens zetelde in de correctionele rechtbank die zich over die zaak moest buigen in graad van beroep tegen de beslissing van de politierechtbank, gaf aanleiding tot een vernietiging op grond van art. 292 Ger.W. (Cass. I9 december 1984, Arr. Cass. 1984-85, nr. 247; Cass. 21 oktober 1987, Arr.Cass. 1987-88, nr. I04; Cass. 3 I januari I989, Arr. Cass. I988-89, nr. 3 I9 en Cass. 24 oktober 2003, Arr.Cass. 2003, nr. 526). Volgens Declercq is dat een misverstand, omdat de rechter dan telkens in de hoedanigheid van rechter in de rechtbank van eerste aanleg optreedt en dus niet in een ander rechterlijk ambt (R. Declercq, Beginselen van Strafrechtspleging, Mechelen, Kluwer, 2007 (4e ed.), nr. I626, 764).

8I Art. 828, $10^{\circ}$ Ger.W.

82 Zie onder meer Cass. 2 oktober I980, Arr.Cass. I980-8I, II8; Cass. 26 september I986, Arr.Cass. I986-87, nr. 50 en Cass. I juni I999, Arr.Cass. I999, nr. 323. Zie ook de verwijzingen in voetnoot 26.

83 Het moet dus wel om een en dezelfde zaak gaan. Het feit dat een rechter een bepaalde beklaagde eerder al eens veroordeeld heeft, levert dus geen bezwaar op voor een tweede berechting van diezelfde beklaagde voor andere feiten (zie Cass. I6 oktober I985, Arr.Cass. I985-86, nr. 97), zelfs niet als beide zaken dezelfde problematiek vertonen (Cass. 2 juni I992, Arr.Cass. I99I-92, nr. 518). Ook het EHRM ziet daar geen probleem in (zie A. Ooms, 'De rechterlijke onpartijdigheid is niet steeds wat ze lijkt. Een historische en prospectieve analyse over de grens tussen objectieve en subjectieve onpartijdigheid', CDPK 2010, 502-503). 
wat gevallen denkbaar waarbij een en dezelfde magistraat verschillende malen kan optreden in dezelfde zaak. Niet altijd zal er dan ook een probleem rijzen op het vlak van het objectieve onpartijdigheidsvereiste. Er moet immers nagegaan worden of de vrees van de betrokken partijen dat de rechter partijdig zal zijn, objectief verantwoord is. ${ }^{84}$ Het spreekt voor zich dat dit aanleiding heeft gegeven tot een veelheid aan rechtspraak, zowel van het EHRM als, wat België betreft, van het Hof van Cassatie. Daaruit zijn een aantal regels inzake onverenigbaarheden ontstaan die er als aanvulling op het verbod vervat in artikel 292 Ger.W. op preventieve wijze voor zorgen dat geen beslissingen tot stand komen waarvan de neutraliteit ter discussie gesteld zou kunnen worden op grond van het objectieve onpartijdigheidsvereiste. Het betreft onder meer volgende regels:

- Wie in een zaak als openbaar ministerie is opgetreden, al was het maar als ondertekenaar van een kantschrift, mag later niet meer in die zaak als rechter optreden, tenzij hij als openbaar ministerie enkel was opgetreden bij het uitstellen van de zaak. ${ }^{85}$ In dat geval heeft men immers geen kennis genomen van de strafvordering. ${ }^{86}$ Ook de loutere aanwezigheid als openbaar ministerie bij de uitspraak in eerste aanleg over de burgerlijke rechtsvordering, belet die magistraat niet om als rechter in graad van beroep zitting te nemen. ${ }^{87}$

- Wie als onderzoeksrechter is opgetreden, al was het maar tijdelijk en als plaatsvervanger, mag later in beginsel niet meer als rechter ten gronde uitspraak doen over de zaak. ${ }^{88}$ Enige nuancering is hier wel op zijn plaats. Vereist is immers dat de magistraat als onderzoeksrechter kennis heeft genomen van de zaak. ${ }^{89}$ Het EHRM onderzoekt sedert de zaak Hauschildt of er een objectief gerechtvaardigde vrees van partijdigheid is ontstaan door het eerdere optreden als onderzoeksrechter..$^{\circ}$ Daaruit volgt dat het EHRM er niet noodzakelijk een probleem

84 Zie bijvoorbeeld EHRM 25 februari 1997, Findlay t. Verenigd Koninkrijk, §73 en $\$ 76$. Zie ook Cass. 9 april 2003, Arr.Cass. 2003, nr. 236 en JLMB 2003, I539; Cass. 28 januari 2004, Arr.Cass. 2004, nr. 50 en P. Lambert, 'Vers un assouplissement de la notion d'impartialité objective', JT I993, 390 .

85 Cass. 26 april 1977 , Arr.Cass. 1977, 880.

86 Zie F. Kuty, L'impartialité du juge en procédure pénale. De la confiance décrétée à la confiance justifiée, Brussel, Larcier, 2005, 353.

87 Cass. 8 september I998, Arr.Cass. I998, nr. 389 .

88 Vóór het arrest De Cubber t. België (EHRM 26 oktober I984) werd dat wel aanvaard op basis van het feit dat de onderzoeksrechter zich niet uitspreekt over de schuld van de verdachte (zie bijvoorbeeld Cass. 4 april I984, Arr.Cass. I983-84, nr. 448; zie ook B. Maes, 'De onverenigbaarheid van het ambt van onderzoeksrechter met dat van rechter in eerste aanleg of appelrechter en het recht van de beklaagde op een onpartijdige rechtbank', RW I98I-82, I857-I870). Vrij snel na het arrest De Cubber wijzigde het Hof van Cassatie van koers (zie bijvoorbeeld Cass. 23 januari I985, Arr. Cass. I984-85, nr. 302).

89 Zo levert geen probleem op het feit dat een rechter vroeger als onderzoeksrechter enkel een verzoekschrift in ontvangst heeft genomen inzake opheffing van beslag (Cass. I9 mei I987, Arr.Cass. I986-87, nr. 553) of het feit dat hij eenmalig een andere onderzoeksrechter heeft vervangen bij de uitspraak van de raadkamer over de voorlopige hechtenis (Cass. I8 juli I985, Arr.Cass. I984-85, nr. 66I). Zie ook de voorbeelden gegeven in voetnoot 8 o.

90 EHRM 24 mei I989, Hauschildt t. Denemarken. In die zaak werd toch een schending van het objectieve onpartijdigheidsvereiste vastgesteld omdat de vonnisrechter eerder als 'dwangmiddelenrechter' had moeten oordelen of er tegen de verdachte voldoende vermoedens van schuld bestonden (zie \$48-53). 
mee heeft dat een magistraat van een rechtscollege dat zich over de grond van de zaak moet buigen, eerder als onderzoeksrechter een of meerdere onderzoeksdaden heeft gesteld. ${ }^{91}$ Pas als de rechter als onderzoeksrechter uitvoerig gebruik heeft gemaakt van zijn onderzoeksbevoegdheden, is het latere optreden als rechter voor het EHRM onverenigbaar met het objectieve onpartijdigheidsvereiste..$^{92}$

- Wie als zetelend rechter in de raadkamer of de kamer van inbeschuldigingstelling kennis heeft genomen van een zaak, kan later niet meer optreden als rechter ten gronde in die zaak. ${ }^{93}$ Daarbij maakt het niet uit of het onderzoeksgerecht daarbij oordeelde over de regeling der rechtspleging ${ }^{94}$ of over de voorlopige hechtenis. ${ }^{95}$ Wel moet ook in dit geval nagegaan worden of de desbetreffende magistraat effectief kennis heeft genomen van de zaak, wat bijvoorbeeld volgens het Hof van Cassatie niet het geval is indien enkel en alleen een door een bepaalde partij ingesteld rechtsmiddel niet-ontvankelijk wordt verklaard..$^{96}$ Beslist werd ook dat wanneer een magistraat als lid van het onderzoeksgerecht beslist heeft over de voorlopige hechtenis van een verdachte, hij nadien toch zitting mag houden in het vonnisgerecht om uitspraak te doen over een door die verdachte ingediend verzoek tot voorlopige invrijheidstelling. ${ }^{97}$ Ook hier is de rechtspraak van het EHRM eigenlijk nog soepeler,,$^{98}$ wat soms tot onzekerheid aanleiding kan geven.

- Wie als rechter uitspraak heeft gedaan over de grond van de zaak, kan van diezelfde zaak geen kennis meer nemen in een andere rechtbank of kamer en in een andere hoedanigheid. ${ }^{99} \mathrm{Zo}$ is het niet toegestaan dat een rechter die kennis heeft genomen van een zaak in een burgerlijke rechtbank, nog uitspraak zou doen over dezelfde zaak in een strafprocedure, of omgekeerd. ${ }^{100}$ Evenmin kan een rechter die zitting heeft gehad in een rechtscollege dat een strafrechtelijke veroordeling heeft uitgesproken nadien nog deel uitmaken van de burgerlijke kamer van het hof van beroep dat te beslissen heeft over een echtscheiding die - zoals vroeger mogelijk was - wordt gevraagd op basis van diezelfde strafrechtelijke

9I Zie bijvoorbeeld EHRM 24 februari 1993, Fey t. Oostenrijk, \$34-37; EHRM 24 augustus I993, Nortier t. Nederland, \$33-37 en EHRM 22 februari i996, Bulut t. Oostenrijk, §3I-34.

92 Zie bijvoorbeeld EHRM 25 juli 2000, Tierce e.a. t. San Marino, \$78-83.

93 Ook deze onverenigbaarheid werd vroeger, vóór het arrest De Cubber, wel aanvaard (R. Verstraeten, Handboek Strafvordering, Antwerpen, Maklu, 2007 (4e ed.), nr. r6r7, 778).

94 Zie voor een toepassingsgeval bijvoorbeeld Cass. 3I januari I989, Arr.Cass. I988-89, nr. 3 I9.

95 Zie bijvoorbeeld Cass. 2 oktober 1985 , Arr.Cass. 1985-86, nr. 58 en Cass. 9 februari ig88, Arr.Cass. r987-88, nr. 347 .

96 Zie Cass. II februari I987, Arr.Cass. I986-87, 780 en Cass. 23 januari r99I, Arr.Cass. I990-9I, nr. 272.

97 Cass. I3 september I989, Arr.Cass. I989-90, nr. 32; Cass. I9 januari 1993, Arr.Cass. I993, nr. 38; Cass. 23 januari 1996, Arr.Cass. I996, nr. 49 en RW I996-97, 537.

98 Zie bijvoorbeeld EHRM 22 april 1994 , Saraiva De Carvalho t. Portugal.

99 Het levert evenwel geen probleem op als die rechter enkel wordt aangewezen om een verhinderde rechter te vervangen op het ogenblik van de uitspraak (Cass. 23 oktober 1997, Arr.Cass. I997, nr. 424).

Ioo R. Verstraeten, Handboek Strafvordering, Antwerpen, Maklu, 2007 (4e ed.), nr. I6I9, 780-78r. Zie bijvoorbeeld Luik I3 november I990, JLMB I99I, 278. 
veroordeling. ${ }^{\text {Ior }}$ Een rechter die in kort geding uitspraak heeft gedaan over een zaak en daarbij reeds zijn mening heeft gegeven over de later door de burgerlijke partij aangeklaagde feiten, mag in die zaak ook niet meer optreden als onderzoeksrechter. ${ }^{\mathrm{I02}}$

- Het voorgaande belet niet dat een rechter in dezelfde rechtbank verschillende malen uitspraak doet in dezelfde zaak. In dat geval is er dus geen sprake van een verboden cumulatie. Zo levert het feit dat de rechter die bij verstek vonniste later over het verzet uitspraak doet, geen schending op van het recht op een onafhankelijke en onpartijdige rechter. ${ }^{103}$ De rechter die als alleenzetelend magistraat een zaak heeft verwezen naar een kamer met drie rechters, mag achteraf ook van deze zetel deel uitmaken. ${ }^{104}$ De meeste rechtspraak in dit verband heeft evenwel betrekking op het herhaaldelijk zetelen in een onderzoeksgerecht in dezelfde zaak, omdat de onderzoeksgerechten en zeker de kamers van inbeschuldigingstelling omwille van de diverse opdrachten die zij vervullen dikwijls verschillende malen te beslissen hebben in een en dezelfde zaak. ${ }^{105} \mathrm{Zo}$ is het feit dat een rechter reeds gezeteld heeft in de raadkamer in het kader van de voorlopige hechtenis geen beletsel om nadien als rechter in diezelfde raadkamer over de grond van de zaak te oordelen en de internering van de inverdenkinggestelde te gelasten. ${ }^{106}$ Een raadsheer mag ook, telkens in de kamer van inbeschuldigingstelling, mee beslissen over zowel de controle op de voorlopige hechtenis als over de controle op de bijzondere opsporingsmethoden, nu beide procedures een ander voorwerp hebben omdat in het eerste geval een prima facie onderzoek van de wettigheid en de regelmatigheid van de procedure volstaat en in het tweede geval een exhaustieve controle ervan noodzakelijk is. ${ }^{107}$ Dergelijke cumulaties kunnen er wel toe leiden dat een rechter voor de situatie komt te staan dat hij een beslissing zou moeten nemen die een erkenning inhoudt van het foutieve karakter van een eerdere beslissing. Men kan zich afvragen of men dan nog wel voldoende onbevangen kan oordelen. Om die reden is Kuty van oordeel dat het prima facie onderzoek en het exhaustieve onderzoek van de regelmatigheid en de wettelijkheid van de procedure best door verschillende rechters wordt gevoerd. ${ }^{108}$ Bovendien is er dan nog het probleem dat de kamer van inbeschuldigingstelling in het kader van de controle op de bijzondere opsporingsmethoden

Ior Cass. I9 mei i988, Arr.Cass. I987-88, nr. 582.

I02 Cass. I3 mei I992, Arr.Cass. I99I-92, nr. 472.

I03 Zie onder meer Cass. 3 februari I987, Arr.Cass. I986-87, nr. 323 en Cass. 5 mei I999, Arr.Cass. I999, $\mathrm{nr} .263$.

I04 Zie onder meer Cass. 27 juni 1989, Arr.Cass. I988-89, nr. 632 en Cass. 22 januari I99I, Arr.Cass. I990-9I, nr. 265.

I05 Zie hierover ook W. De Pauw, 'De objectieve onpartijdigheid en de extensieve bevoegdheden van de kamer van inbeschuldigingstelling: een subtiel evenwicht?', noot onder Cass. Io juni 20Io, RABG 20II, 62I-626. Zie voor toepassingsgevallen bijvoorbeeld Cass. 2I maart 2000, Arr.Cass. 2000, 639, Cass. 8 mei 200I, Arr.Cass. 201, 830 en Cass. 30 mei 200I, Arr.Cass. 2001, I037.

Io6 Cass. 6 november ig85, Pas. I986, I, nr. I5I.

I07 Cass. Io juni 20II, RABG 20II, 619, met noot W. De Pauw.

Io8 F. Kuty, L'impartialité du juge en procédure pénale. De la confiance décrétée à la confiance justifiée, Brussel, Larcier, $2005,6 \mathrm{II}$. 
observatie en infiltratie ook kennis neemt van het vertrouwelijk dossier, ${ }^{109}$ zodat de raadsheren die in een later stadium te oordelen hebben over bijvoorbeeld de voorlopige hechtenis of over de regeling der rechtspleging dan kennis kunnen hebben van meer gegevens dan de verdediging.

Ter vrijwaring van de neutraliteit van de rechter, legt de wet nog enkele bijkomende regels op. Zo is bepaald dat echtgenoten of bloed- en aanverwanten tot en met de graad van oom en neef niet samen van eenzelfde hof of rechtbank mogen deel uitmaken als (plaatsvervangend) rechter of raadsheer. ${ }^{\text {IIo }}$ Weliswaar kan vrijstelling worden verleend door de Koning, maar als dat gebeurt kunnen de betrokkenen in elk geval nooit zitting nemen in eenzelfde zaak. ${ }^{\text {III }}$ Dat verbod geldt wel maar binnen eenzelfde hof of rechtbank, ${ }^{\mathrm{II} 2}$ zodat vreemd genoeg de wet zich er niet tegen verzet dat over een vonnis gewezen in eerste aanleg mede beslist wordt in graad van beroep door bijvoorbeeld de echtgenoot van de eerste rechter. ${ }^{113}$ Dat is nochtans geen wenselijke toestand, omdat het kan leiden tot legitieme twijfel over de neutraliteit van de kwestieuze appelrechter. Ook artikel 292 van het Gerechtelijk Wetboek is op deze situatie niet van toepassing. Aangenomen moet echter worden dat in dergelijke gevallen de betrokken appelrechter zich moet onthouden van de zaak en dat, voor zover dat niet zou gebeuren, een wraking mogelijk is op grond van het algemeen rechtsbeginsel van de onafhankelijkheid en de onpartijdigheid van de rechter.

Verder is bepaald dat, maar dat is eerder een regel ter vrijwaring van de subjectieve neutraliteit van de rechter, een rechter zich op straffe van tuchtsanctie moet onthouden als hij echtgenoot, bloed- of aanverwant in de rechte lijn of in de tweede graad in de zijlijn is van de advocaat of van de gemachtigde van een der partijen. ${ }^{\mathrm{II} 4} \mathrm{Zo}$ is nietig het arrest dat gewezen is door een rechtscollege waarin zitting werd genomen door een toegevoegd rechter die de vader was van de advocaat van één der partijen. ${ }^{\text {II }}$

In zijn omstandige doctoraatsthesis over de onpartijdigheid van de rechter wijst Kuty erop dat ook een aantal procedurele regels van het strafprocesrecht bijdragen

Io9 Zie artikel 235ter Sv.

IIo Art. 30I Ger.W.

III Art. 302 Ger.W.

II2 Cass. I7 mei I985, Arr.Cass. I984-85, I28I.

II3 In strafzaken wordt in graad van beroep beslist door drie rechters (ingeval van hoger beroep tegen beslissingen van de politierechtbank) of raadsheren (ingeval van hoger beroep tegen beslissingen van de correctionele rechtbank). In burgerlijke zaken kan het hoger beroep wel worden afgehandeld door één raadsheer.

II4 Art. 304 Ger.W.

II5 Cass. I8 april I99I, Arr.Cass. I990-9I, 843 en JT I99I, 726. 
aan de neutraliteit van de strafrechter. ${ }^{116}$ Volgende procedurele regels en rechten worden daarbij vermeld: de tegensprekelijkheid van de debatten, het feit dat de beslissende rechters ook alle zittingen over die zaak moeten hebben bijgewoond, de verplichting tot motivering, de openbaarheid van de terechtzitting en van de uitspraak, het mondeling karakter van de rechtspleging ten gronde, de gelijkheid van wapens, de collegiale samenstelling van (sommige) rechtsprekende instanties, de meerderheidsvereisten bij het beraad en de rechtsmiddelen.

De tegensprekelijkheid van de debatten wordt als een fundamentele waarborg voor de neutraliteit van de strafrechter beschouwd, aangezien de rechter zijn oordeel pas mag vellen tijdens het beraad en dus nadat de debatten werden gevoerd. De rechter kan zijn overtuiging dan ook maar tot uiting brengen eens hij volledig geïnformeerd is, het volledige dossier kent $^{\mathrm{II} 7}$ en de argumenten van de verdediging heeft aangehoord. ${ }^{\mathrm{II} 8}$ Verder mag hij zijn overtuiging uitsluitend gronden op elementen die aan de tegenspraak werden onderworpen ${ }^{119}$ en dus bijvoorbeeld niet op elementen die hem slechts ter kennis zijn gekomen tijdens het beraad. Kuty voegt eraan toe dat de rechter blijk moet geven van een 'open geest' en bijvoorbeeld in staat moet zijn om terug te komen op een eerste of eerdere indruk indien nieuwe elementen daartoe nopen. ${ }^{120}$ Die open geest moet de rechter er ook toe brengen de beklaagde in de mogelijkheid te stellen zijn rechten van verdediging op een zo volledig mogelijke wijze te kunnen uitoefenen. Zo mag niet willekeurig of op basis van vooringenomenheid geweigerd worden om bepaalde door de verdediging aangebrachte getuigen te horen, maar moet de rechter openstaan voor elke mogelijke piste of onderzoeksmaatregel die de waarheid ten goede kan komen. Verwant met de tegensprekelijkheid van de debatten, zijn verder nog het mondeling karakter van de rechtspleging ten gronde en de gelijkheid van wapens, omdat zij de tegenspraak bevorderen en derhalve meedragen aan de neutraliteit van de strafrechter.

II6 Zie F. Kuty, L'impartialité du juge en procédure pénale. De la confiance décrétée à la confiance justifiée, Brussel, Larcier, 2005, 130-176.

II7 Wanneer er sprake is van een plotse wissel van rechters en het strafdossier omvangrijk is, kan er een gewettigde vrees ontstaan bij de beklaagde dat de rechter het strafdossier onvoldoende meester is, wat kan meespelen in de overweging dat het recht op een eerlijk proces is aangetast (zie bijvoorbeeld EHRM 6 december I988, Barberà, Messegué \& Jabardo t. Spanje, \$72 en 89).

II8 De verdediging heeft overigens altijd het laatste woord, maar in politiezaken of correctionele zaken moet de beklaagde alleen als laatste aan het woord gelaten worden als hij daarom verzocht heeft (Cass. II oktober 2000, Arr.Cass. 2000, 1556).

II9 Dat verbod verhindert evenwel niet dat hij gebruik maakt van algemeen bekende feiten, ook al zijn die niet aan de oppervlakte gekomen in het debat, in het dossier of naar aanleiding van een tegensprekelijk uitgevoerde onderzoeksmaatregel. Dergelijke feiten maken immers automatisch deel uit van het debat net omdat ze algemeen bekend zijn (cf. Cass. 7 februari 2006, NC 2008, I8I), wat wil zeggen dat het om feiten en omstandigheden gaat die elke redelijke burger met een gemiddelde ontwikkeling en kennis kent of geacht wordt te moeten kennen (Ph. Traest, Het bewijs in strafzaken, Gent, Mys \& Breesch, I992, nr. 739). Zie over deze problematiek B. Allemeersch, De naakte grijsaard. Over de rechter en zijn persoonlijke kennis(sen), Antwerpen, Intersentia, 2009, 35 p.

I20 F. Kuty, L'impartialité du juge en procédure pénale. De la confiance décrétée à la confiance justifiée, Brussel, Larcier, 2005, I35. 
De verplichting dat de rechter die over de zaak beslist ook alle zittingen over die zaak heeft bijgewoond, wat op straffe van nietigheid is voorgeschreven, ${ }^{\mathrm{I} 2 \mathrm{I}}$ garandeert verder de neutraliteit van de rechter, omdat ook in een collegiale samenstelling alle rechters alle debatten moeten hebben bijgewoond. Moet de samenstelling om een of andere reden worden gewijzigd, dan moeten de debatten worden hernomen. Zodoende wordt vermeden dat een rechter die niet alle debatten heeft bijgewoond, deel zou uitmaken van de zetel, wat er immers toe kan leiden dat die rechter zich zou kunnen baseren op een vooringenomen oordeel over de zaak dat hij niet heeft kunnen toetsen aan alle elementen die ter zitting werden naar voren gebracht.

De verplichting om vonnissen te motiveren, is in België grondwettelijk verankerd. ${ }^{122}$ In strafzaken bestaat de motiveringsverplichting uit drie delen: ${ }^{\mathrm{I} 23}$ vooreerst moet de rechter de schuld van de beklaagde vaststellen, vervolgens moet de rechter de aard van de straf bepalen en ten slotte moet hij de hoogte van de straf vastleggen. ${ }^{124} \mathrm{De}$ motivering verplicht de rechter niet alleen om verantwoording voor zijn beslissing te zoeken, maar ook om deze te expliciteren. ${ }^{125}$ De verplichting om te motiveren wordt bovendien gezien als een waarborg tegen willekeur. ${ }^{126}$ In de motivering moet de beklaagde als het ware het bewijs kunnen vinden dat zijn veroordeling niet willekeurig is geweest. ${ }^{127}$ In een recent arrest heeft het Hof van Cassatie gepreciseerd dat de rechter zelfs wanneer er geen conclusies worden neergelegd, verplicht is de overwegingen te vermelden die hem hebben overtuigd van de schuld of onschuld van de beklaagde en dat hij minstens de voornaamste redenen moet vermelden waarom de tenlastelegging al dan niet bewezen werd verklaard. ${ }^{\mathrm{I} 2}$ Dat is een hele stap vooruit, omdat vroeger bij gebrek aan conclusie de rechter enkel moest vaststellen dat de beklaagde het misdrijf gepleegd heeft, zonder dat hij de gegevens moest vermelden waaruit hij de schuld van de beklaagde heeft afgeleid. ${ }^{129}$ Anderzijds is de motiveringsverplichting niet meer dan een vormvoorschrift, zodat een onjuiste, onaangepaste, onvolledige of zelfs in rechte verkeerde of niet-toepasselijke motivering geen grond oplevert tot cassatie. ${ }^{130}$

I2I Art. 779, I alinea Ger.W.

I22 Art. I49 GW.

I23 S. Van Overbeke, 'De motivering van de straf in correctionele zaken volgens artikel I95, 2e lid Sv.', RW I992-93, 538 .

I24 Zie de artikelen I63, I95 en 2 II Sv.

I25 F. Dumon, 'De motivering van vonnissen en arresten en de bewijskracht van de akten', RW I978I979, 260 .

I26 Zie Cass. I2 mei I932, Pas. I932, I66. Ook het EHRM heeft zich reeds herhaaldelijk in die zin uitgelaten (zie bijv. nog EHRM I6 november 20I0, Taxquet t. België, §9o).

I27 Zie L. Bore, 'La motivation des décisions de justice et la Convention européenne des droits de l'homme', JCP 2002, I2I-I27.

I28 Cass. 8 juni 20II, JT 20II, 490-49I.



I30 Zie R. Declercq, Beginselen van strafrechtspleging, Mechelen, Kluwer, 2007 (4e ed.), nr. I457, 682 en de verwijzingen aldaar. 
Ook de openbaarheid van de terechtzitting en van de uitspraak kan als waarborg voor de neutraliteit van de strafrechter worden gezien, ${ }^{\mathrm{I} 3 \mathrm{I}}$ omdat het willekeur tegengaat. Het feit dat eenieder de debatten in beginsel kan bijwonen en derhalve de houding van de rechter gadeslaan, versterkt bovendien de neutraliteit, omdat het de rechter verplicht om zijn onpartijdigheid ook daadwerkelijk uit te stralen.

Verder is er nog de collegiale samenstelling van sommige rechtsprekende instanties. In strafzaken wordt in graad van beroep beslist door een college van drie rechters of raadsheren. In eerste aanleg daarentegen, wordt beslist door een alleenzetelende rechter, met dien verstande dat bepaalde misdrijven verplichtend aan een kamer met drie rechters worden toegewezen en dat het openbaar ministerie steeds kan oproepen of dagvaarden voor een kamer met drie rechters, net zoals ook de beklaagde een verwijzing naar een kamer met drie rechters kan vragen. ${ }^{132}$ Waar historisch gezien het principe van de collegiale beslissing in strafzaken de algemene regel uitmaakte, ${ }^{133}$ is men omwille van de steeds toenemende gerechtelijke achterstand geleidelijk overgestapt naar de alleenzetelende rechter in eerste aanleg als algemene regel, weliswaar met enkele uitzonderingen en met de mogelijkheid om van deze regel af te wijken. Op zich is daar uiteraard niets mis mee, aangezien niet alle strafzaken een behandeling door drie rechters vereisen en er overigens in strafzaken tegen beslissingen van een alleenzetelend rechter altijd hoger beroep kan worden ingesteld. ${ }^{134}$ Toch kan men er niet omheen dat collegiale rechtspraak alleen maar bevorderlijk kan zijn, niet alleen voor de kwaliteit van de rechtspraak, maar evenzeer ter vrijwaring van de onafhankelijkheid en de neutraliteit van de strafrechter. ${ }^{135}$ Door collegiale rechtspraak wordt immers het gevaar geneutraliseerd dat uitgaat van een te grote invloed van persoonlijke opvattingen of moraal van een welbepaalde rech$\operatorname{ter}^{136}$ en worden rechters beschermd tegen eventuele verwijten van partijdigheid of van een gebrek aan onafhankelijkheid. ${ }^{137}$ Ook vele buitenlandse auteurs wijzen erop dat de collegiale samenstelling een belangrijke waarborg uitmaakt voor de

I3I In België is de uitspraak altijd openbaar, maar kan van de openbaarheid van de terechtzitting worden afgeweken (zie artikelen I48 en I49 GW en I53, I90 en 2II Sv). Dat geldt ook voor assisenzaken.

I32 Zie de artikelen 9I en 92 Ger.W.

I33 Zie hierover Ph. Traest, 'Enkele bedenkingen over de alleenzetelende rechter in strafzaken', in F. Deruyck, M. De Swaef, J. Rozie, M. Rozie, Ph. Traest en R. Verstraeten (eds.), De wet voorbij. Liber Amicorum Luc Huybrechts, Antwerpen, Intersentia, 20I0, 4I6.

I34 In strafzaken is hoger beroep altijd mogelijk, behoudens tegen beslissingen van de hoven van assisen of tegen arresten die door het hof van beroep in eerste en laatste aanleg zijn gewezen bij voorrecht van rechtsmacht of bij de berechting van ministers. In die gevallen betreft het uiteraard geen beslissingen van een alleenzetelend rechter.

I35 Zie hierover ook F. Kuty, L'impartialité du juge en procédure pénale. De la confiance décrétée à la confiance justifiée, Brussel, Larcier, 2005, I6I-I62.

I36 M. Buyst en G. De Roover, 'Rechterlijke macht en macht van één rechter', in X., Tien jaar Gerechtelijk Wetboek, Antwerpen, Kluwer, I98I, 88. Zie ook A. Meeus, 'L'art de juger', in X., Mélanges R. Legros, éditions de la Faculté de droit de l'université Libre de Bruxelles, I985, 44I.

I37 Ph. Traest, 'Enkele bedenkingen over de alleenzetelende rechter in strafzaken', in F. Deruyck, M. De Swaef, J. Rozie, M. Rozie, Ph. Traest en R. Verstraeten (eds.), De wet voorbij. Liber Amicorum Luc Huybrechts, Antwerpen, Intersentia, 20I0, 426. In dezelfde zin R. de Gouttes, 'L'impartialité du juge. Connaître, traiter et juger: quelle compatibilité?', RSC 2003, 77. Er moet wel op gewezen worden dat een collegiaal samengestelde rechtbank ook partijdig kan worden bevonden wan- 
rechtsonderhorige, ${ }^{138}$ zelfs in die mate dat soms gesproken wordt van 'un principe fondamental de l'exigence d'impartialité'. ${ }^{139}$ De invoering van een college van onderzoeksrechters in Frankrijk $\mathrm{k}^{140}$ toont overigens aan dat men er van oordeel is dat er beter beslist wordt door meerdere rechters dan door een enkele rechter, al was deze wijziging in mindere mate ingegeven door het neutraliteitsvereiste maar eerder om gerechtelijke dwalingen tegen te gaan. Anderzijds wijst Kuty erop dat een collegiale samenstelling niet geheel risicoloos is omdat een berechting door meerdere rechters ook de mathematische kans vergroot dat men een 'slechte' rechter treft die dan bovendien misschien wel, zeker als hij kamervoorzitter is, de andere rechters overschaduwt in de beraadslaging. ${ }^{\mathrm{II}}$

Indien aangenomen wordt dat de collegiale samenstelling van een rechtscollege de neutraliteit bevordert, dan mag er aan toegevoegd worden dat die neutraliteit versterkt wordt door de toepasselijke meerderheidsregels. In strafzaken geldt immers in alle zaken behalve in criminele zaken, dat beslist wordt met een absolute meerderheid der stemmen en dat, als er meer dan twee gevoelens worden uitgedrukt, de rechters die zich het minst gunstig voor de beklaagde hebben uitgesproken, verplicht zijn zich met een van de andere gevoelens te verenigen. ${ }^{\mathrm{I} 2}$ In graad van beroep kan een verzwaring van de toestand van de beklaagde bovendien slechts indien er sprake is van eenparigheid van stemmen. ${ }^{143}$ In criminele zaken, waarbij over de schuldvraag beslist wordt door een volksjury bestaande uit twaalf juryleden, leidt een schuldigverklaring bij gewone meerderheid ertoe dat de drie beroepsrechters zich moeten uitspreken. De beschuldigde wordt dan vrijgesproken indien de meerderheid van deze beroepsrechters het standpunt van de meerderheid van de jury niet volgt. ${ }^{\text {I44 }}$ Deze meerderheidsregels hebben tot gevolg dat als een rechter die deel uitmaakt van het rechtscollege niet geheel onpartijdig zou zijn, diens opinie niet doorslaggevend kan zijn. Evenwel zegt dat niets over de feitelijke overredingskracht van die rechter en is het uiteraard niet uitgesloten dat die rechter een of meer collega's kan beïnvloeden. Het betreft dan ook een element dat slechts zeer indirect kan bijdragen aan het neutraliteitsvereiste.

Ten slotte vermeldt Kuty nog de rechtsmiddelen, die er in strafzaken toe strekken dat de zaak behandeld zal worden door een college van rechters of raadsheren. Van de

neer slechts één van de daarvan deel uitmakende rechters daadwerkelijk partijdig blijkt te zijn (zie EHRM 2 maart 1995, Ferrantelli \& Santangelo t. Italië, \$59).

I38 Zie onder meer P. Truche, Juger, être jugé, Paris, Fayard, 200I, I5 en P. Drai, 'Le délibéré et l'imagination du juge', in X., Mélanges R. Perrot, Paris, Dalloz, I996, IIg.

I39 D. Allix, Les droit fondamentaux dans le procès pénal, Paris, Montchrestien, I997, 77.

I40 Zie art. 83 CPP, in werking sedert I januari 20Io. Zie hierover J. Meese, 'Sire, er zijn geen onderzoeksrechters meer. De toekomst van het gerechtelijk onderzoek: Frankrijk als inspiratiebron?', in F. Deruyck, M. De Swaef, J. Rozie, M. Rozie, Ph. Traest en R. Verstraeten (eds.), De wet voorbij. Liber Amicorum Luc Huybrechts, Antwerpen, Intersentia, 20Io, nr. 2, 276.

I4I F. Kuty, L'impartialité du juge en procédure pénale. De la confiance décrétée à la confiance justifiée, Brussel, Larcier, 2005, 162.

I42 Zie de artikelen I72, 2e lid, I93bis en 2II Sv.

I43 Art. 2Irbis Sv.

I44 Art. 335 Sv. 
rechtsmiddelen gaat zowel een preventief als een curatief effect uit. ${ }^{145}$ Inderdaad zullen rechters die weten dat hun beslissing getoetst kan worden door een hogere instantie, automatisch geneigd zijn om een beslissing te nemen waarvan geen blijk van partijdigheid uitgaat. Gebeurt dat toch, dan kan die beslissing worden hervormd, wat dan het curatieve aspect uitmaakt. Anderzijds kan het probleem van partijdigheid zich ook voor het eerst stellen in graad van beroep, in welk geval de mogelijkheid tot hervorming van de beslissing dus negatief uitvalt. In dat geval is er wel de garantie van collegialiteit en van het vereiste van eenparigheid van stemmen bij strafverzwaring.

\section{Afwijkende regimes voor bepaalde categorieën van personen}

Voor bepaalde categorieën van personen gelden specifieke procedures. In dit verband kan verwezen worden naar het voorrecht van rechtsmacht dat van toepassing is op onder meer magistraten en naar de bijzondere procedure die geldt voor de berechting van ministers. Die bijzondere regimes hebben onder meer tot doel de neutraliteit te waarborgen van de strafrechter voor de categorieën van personen waarop ze betrekking hebben. Een uitvoerige bespreking van deze regimes past niet in het bestek van dit preadvies, zodat slechts enkele hoofdlijnen worden weergegeven.

\subsection{Voorrecht van rechtsmacht}

Wanneer een persoon die beschikt over het voorrecht van rechtsmacht (bijvoorbeeld een rechter of een raadsheer), ${ }^{146}$ vervolgd wordt wegens een misdrijf dat een correctionele straf meebrengt, gelden specifieke bevoegdheidsregels. ${ }^{147}$ Vooreerst kan over het instellen van de strafvordering enkel en alleen beslist worden door de procureurgeneraal bij het hof van beroep of, voor hogere magistraten (leden van een hof of van het parket bij een hof), door de procureur-generaal bij het Hof van Cassatie. In dat laatste geval moet het Hof van Cassatie dan nog beslissen of er voldoende bezwaren zijn om te verwijzen naar een hof van beroep. ${ }^{148}$ Verder moet de betrokkene in beide gevallen berecht worden door het hof van beroep, in eerste en laatste aanleg. ${ }^{49} \mathrm{Waar}$ het eerste voornamelijk is ingegeven door de bezorgdheid dat personen met een bijzonder ambt niet zouden worden blootgesteld aan lichtzinnige vervolging (bijvoorbeeld door een klacht van degene die zij berecht hebben), is het feit dat over de strafvordering tegen die personen beslist wordt door het hof van beroep ingegeven door de wil om in een zo neutraal mogelijke strafrechter te voorzien. Meer bepaald

I45 F. Kuty, L'impartialité du juge en procédure pénale. De la confiance décrétée à la confiance justifiée, Brussel, Larcier, 2005, I65.

I46 Zie de opsomming in artikel $479 \mathrm{~Sv}$.

I47 Zie hierover onder meer J. De Codt, 'De vervolging van magistraten', in X., Statuut en deontologie van de magistraat, Brugge, Die Keure, 2000, I5I-I82.

I48 Zie de artikelen $48 \mathrm{I}-482 \mathrm{~Sv}$.

I49 Betreft het een vervolging voor misdaden waarvoor geen correctionalisering mogelijk of wenselijk is, dan wordt de betrokkene net zoals andere rechtsonderhorigen berecht door het hof van assisen en is enkel de wijze van aanhangigmaking anders. 
wenste men te vermijden dat magistraten beoordeeld zouden worden door hun naaste collega's die zich in een dubbelzinnige situatie bevinden die aanleiding zou kunnen geven tot een al te grote gestrengheid dan wel een al te grote tolerantie. ${ }^{150}$ Alhoewel het een voorrecht wordt genoemd, leidt de toepassing van het voorrecht van rechtsmacht tot een aanzienlijke inperking van waarborgen. Behoudens het feit dat over het instellen van een strafvervolging slechts kan worden beslist door het openbaar ministerie en dus niet door een benadeelde, wordt de betrokkene immers vooral geconfronteerd met een inperking van waarborgen, zoals het verlies van een aanleg. Het systeem is dan ook geenszins van kritiek gespaard gebleven. ${ }^{\mathrm{IrI}}$ Bovendien worden mededaders en medeplichtigen aan de misdrijven gepleegd door een persoon met voorrecht van rechtsmacht, alsook de daders van samenhangende misdrijven, samen met de persoon met voorrecht van rechtsmacht berecht. ${ }^{152}$ Zodoende is die duistere procedure ook van toepassing op hen. Daar komt nog bij dat de rechtspraak sinds oudsher aanvaardt dat de procedure van voorrecht van rechtsmacht ook van toepassing is op plaatsvervangende rechters, ${ }^{153}$ niettegenstaande deze categorie van personen niet vermeld wordt in artikel $479 \mathrm{~Sv}$ en de in die bepaling gegeven opsomming nochtans als limitatief wordt beschouwd, ${ }^{154}$ wat vragen doet rijzen bij de (grond)wettelijkheid van deze uitbreiding. ${ }^{155}$ De combinatie van beide uitbreidingen lijkt in sommige complexe strafdossiers, waarvoor de berechting binnen een redelijke termijn of binnen de verjaringstermijn niet lijkt te lukken, tot de verleiding te zorgen bij sommige parketmagistraten om op een nogal inventieve wijze op zoek te gaan naar een plaatsvervangend magistraat die misschien mee vervolgd kan worden als mededader of medeplichtige of als dader van een samenhangend misdrijf. Die beslissing is immers, behalve indien het om hogere magistraten gaat, ${ }^{156}$ niet aan rechterlijke toetsing onderhevig. En wordt die plaatsvervangend magistraat

I50 J. Constant, 'Crimes commis par les juges', Les Novelles, Procédure pénale, II, Brussel, I949, nr. 3.

I5I Zie bijv. R. Verstraeten, 'Voorrecht van rechtsmacht', in L. Dupont en B. Spriet, Strafrecht voor rechtspractici IV, Leuven, Acco, I99I, randnr. 85, I42-I44, die het stelsel omschrijft als 'duister, lacunair, onnauwkeurig en incoherent'.

I52 Zie art. 482 bis Sv.

I53 Zie onder meer Cass. Io april I843, Pas. I843, I, I4I, Cass. 5 juli I938, Pas. I938, I, 256 en Cass. 7 april I975, Arr.Cass. I975, 852. Zie ook J. Matthijs, 'Openbaar Ministerie', in Algemene Praktische Rechtsverzameling, Deurne, Kluwer, I992, randnr. 666, 329, die het heeft over eensgezindheid bij rechtspraak en rechtsleer. Toch werd de uitbreiding in 1949 reeds gecontesteerd wegens te ruim (J. Constant, 'Crimes commis par les juges', in Les Novelles, Procédure pénale, II, I949, randnr. 6, 36).

I54 Zie onder meer Cass. 7 oktober I963, RW I963-64, I65I en Cass. I5 december I998, Arr.Cass. I998, II35 en JLMB I999, 928.

I55 Art. I3 GW bepaalt dat niemand tegen zijn wil kan worden afgetrokken van de rechter die de wet hem toekent. Een afwijking van de gemeenrechtelijke regeling is slechts met artikel I3 GW verenigbaar indien er een redelijke en objectieve verantwoording aan ten grondslag ligt (K. Rimanque, De grondwet toegelicht, gewikt en gewogen, Antwerpen, Intersentia, 1999, 37). Bovendien is er ook nog artikel 6.I EVRM, dat voorschrijft dat eenieder recht heeft op een behandeling van zijn zaak door een gerecht dat bij de wet is ingesteld. Daarvan kan niet afgeweken worden op basis van jurisprudentie alleen.

I56 In dat geval kan het Hof van Cassatie immers oordelen dat er onvoldoende bezwaren bestaan, dat het feit geen misdrijf is, of dat de strafvordering is verjaard, in welk geval er niet verwezen wordt (zie bijv. Cass. 5 februari 2002, Arr.Cass. 2002, nr. 88). Voor eventuele andere personen ten aanzien van wie wel een verwijzing zich opdringt, moet dan de gemeenrechtelijke procedure worden gevolgd. 
uiteindelijk vrijgesproken, dan heeft dat geen weerslag op de regelmatige aanwending van de procedure van voorrecht van rechtsmacht voor de overige beklaagden, die ondertussen zonder regeling der rechtspleging naar de vonnisrechter verwezen werden en in eerste en laatste aanleg berecht zijn. In dat opzicht moet men zich afvragen of het niet wenselijk is om voor de hier bedoelde personen, wanneer door het openbaar ministerie wordt beslist dat vervolging wenselijk is, te voorzien in een procedure die voor het overige gelijkloopt met de gemeenrechtelijke procedure, met als enig verschil dat men berecht wordt in een ander rechtsgebied dan datgene waar men werkzaam is. Op die manier verliest niemand - niet de magistraat zelf, maar ook niet de personen die samen met hem worden berecht - de waarborgen die men anders wel heeft. Bovendien lijkt er geen bezwaar te zijn wat betreft de neutraliteit van de rechter, nu men steeds hoger beroep kan aantekenen en men dus in laatste aanleg ook berecht wordt door een hof van beroep, net zoals nu het geval is. Men kan zich trouwens afvragen of een berechting in een ander rechtsgebied dan dat waarin men werkzaam is sowieso niet beter is op vlak van neutraliteit van de strafrechter.

\subsection{Berechting van ministers}

Ministers worden, althans sedert $1998,{ }^{157}$ berecht door de algemene vergadering van het hof van beroep te Brussel wanneer het gaat om misdrijven gepleegd in de uitoefening van hun ambt, en door het territoriaal bevoegde hof van beroep wanneer het gaat om misdrijven gepleegd buiten de uitoefening van hun ambt waarvoor zij worden berecht tijdens hun ambtstermijn. ${ }^{158}$ In het eerste geval wordt gezeteld met zeven leden, in het tweede geval met vijf. Ook wat ministers betreft, kan de strafvordering slechts worden ingesteld door het openbaar ministerie, maar daarvoor is wel verlof vereist van de Kamer van volksvertegenwoordigers. ${ }^{159}$ Ook in dit scenario is er sprake van berechting in eerste en laatste aanleg, maar daar staat wel tegenover dat beslist wordt door een groter aantal raadsheren dan in een gemeenrechtelijke procedure het geval is.

\section{B Instrumenten die bijdragen aan de subjectieve neutraliteit}

\section{$1 \quad$ Geen rechter in eigen zaak}

Even evident als het recht op een onpartijdige rechter zelf, is het feit dat men nooit rechter kan zijn in eigen zaak: nemo iudex in causa sua. Dat niemand in een zaak partij en rechter kan zijn is een algemeen rechtsbeginsel ${ }^{160}$ en raakt de openbare orde. De persoonlijke partijdigheid van de rechter in kwestie hoeft dan ook niet te worden

157 Vóór de wijziging van art. I03 GW bij Wet van I2 juni I998 werden zij berecht door het Hof van Cassatie.

I58 Zie hierover onder meer G. Goedertier, 'Het strafrechtelijk statuut van ministers', AJT I998-99, 90I-9Io en E. Liekendael, 'Bescheiden bijdrage tot een beschouwing over een gewichtig probleem: de strafrechtelijke verantwoordelijkheid van de federale ministers', RW I998-99, 449463.

I59 Voor leden van een Gemeenschaps- of Gewestregering geldt een gelijkaardige regeling.

I6o Cass. 20 september I979, Arr.Cass. I979-80, 77. 
aangetoond, omdat deze onverenigbaarheid gegrond is op objectieve vereisten van de rechterlijke organisatie. ${ }^{\mathrm{I} I \mathrm{I}}$ Daarmee is meteen ook weer de moeilijke scheidingslijn aangetoond tussen de objectieve en de subjectieve onpartijdigheid, waarnaar in de inleiding van dit preadvies reeds werd verwezen: alhoewel het voor zich lijkt te spreken dat degene die als rechter zou moeten oordelen over zijn eigen zaak dat niet onbevangen zal kunnen doen en het hier bedoelde verbod derhalve kan beschouwd worden als een instrument om de subjectieve onpartijdigheid te waarborgen, moet die subjectieve partijdigheid niet worden aangetoond en catalogiseert men de onverenigbaarheid tussen rechter en partij als een objectieve vereiste.

Verwant aan het voorgaande, is de regel dat wie als raadsman van een partij is opgetreden, ook al was het maar voor het louter uitstellen van de zaak, later ook niet meer kan optreden als rechter. ${ }^{162}$ Ook dat wordt als een essentiële regel van de rechtsbedeling beschouwd, die zich zelfs uitstrekt tot een andere zaak die, hoewel niet identiek met de eerste, toch dezelfde partijen tegenover elkaar stelt met betrekking tot een geschil waarin dezelfde verweermiddelen worden opgeworpen. ${ }^{163}$

Het respecteren van de plicht tot loyauteit en objectiviteit door de rechter is een deontologische regel die de uitdrukking vormt van de onafhankelijkheid en de onpartijdigheid die bij de uitoefening van het ambt zo belangrijk zijn. De loyauteit brengt met zich dat de rechter eenieder op gelijke wijze en naar best vermogen behandelt (ongeacht de afkomst, de religieuze of politieke overtuiging, het ras of de huidskleur van de betrokken partij), terwijl de objectiviteit vereist dat de rechter de partijen onbevooroordeeld tegemoet treedt en zich voor zijn oordeel niet steunt op persoonlijke kennis van de feiten, ${ }^{164}$ wat ook met zich brengt dat de rechter niet al te eigengereid mag optreden om zelfstandig feiten te verzamelen omdat hierdoor de schijn van partijdigheid gewekt wordt. ${ }^{165}$ De (straf)rechter moet zich volstrekt neutraal opstellen en handelen in alle vrijheid, zonder druk te aanvaarden van de overheid, de publieke opinie of de media, zijn korps en zijn hiërarchie of zelfs van zijn eigen passies en overtuigingen. De rechter mag niet zijn persoonlijk waardenstelsel in de plaats stellen van datgene wat algemeen maatschappelijk aanvaard wordt op het ogenblik van zijn beslissing. Hij mag ook geen zaken bij voorrang behandelen als daar geen objectieve redenen toe bestaan. ${ }^{166}$ Een rechter die getuige is geweest van strafbare feiten mag zelf ook nooit als rechter zetelen in de strafprocedure die

I6I Cass. I3 januari ig86, Arr.Cass. I985-86, nr. 308.

I62 Cass. I3 oktober I975, Arr.Cass. I976, I9I.

I63 Cass. 6 mei I982, Arr.Cass. I98I-82, IogI.

I64 X. De Riemaecker en G. Londers, 'Deontologie en tucht', in X., Statuut en deontologie van de magistraat, Brugge, Die Keure, 2000, 320. In dezelfde zin reeds J. Chevallier, 'Remarques sur l'utilisation par le juge de ses informations personnelles', Rev.trim.dr.civ. 1962, 7, die dit principe overigens onder meer steunt op het vereiste van rechterlijke onpartijdigheid.

I65 B. Allemeersch, De naakte grijsaard. Over de rechter en zijn persoonlijke kennis(sen), Antwerpen, Intersentia, 2009, nr. I4, 7 .

I66 Zie ook art. 4 Ger.W. 
met betrekking tot die feiten wordt gevoerd. ${ }^{167}$ Teneinde zelfs niet de schijn van partijdigheid te wekken, stelt een goed rechter zich derhalve neutraal, sereen, objectief en onafhankelijk op. De rechter die voorafgaand aan de behandeling van de zaak reeds zijn mening te kennen geeft over de zaak zelf of over een deel of een aspect van het geschil, is dan ook niet meer geschikt om als rechter op te treden. ${ }^{168}$ Een rechter heeft ook geen commentaar of publieke verklaringen te geven over zaken die hij onderzoekt, ook al zou hieruit volgens het Hof van Cassatie nog geen bewijs van partijdigheid voortvloeien. ${ }^{169}$ Evenmin kan men deskundige en rechter zijn in dezelfde zaak, ${ }^{170}$ maar er is geen bezwaar tegen dat men uitspraak doet over een identiek rechtsprobleem waaraan men vroeger een gepubliceerde studie heeft gewijd. ${ }^{17 \mathrm{I}}$ Ook het Grondwettelijk Hof wees er reeds op dat een rechter niet kan worden gewraakt louter op grond van meningen die hij heeft uitgedrukt in werken die hij als rechtsgeleerde heeft gepubliceerd, of omdat hij, in andere zaken, reeds beslissingen heeft gewezen die indruisen tegen de aanspraken van één van de partijen. ${ }^{172}$

De vereiste neutraliteit van de rechter brengt ook met zich dat elke rechter die weet dat een van de onverenigbaarheden of gronden van wraking op hem van toepassing zijn, zich spontaan moet onthouden van de zaak, zodra hij tot de vaststelling komt dat er een onverenigbaarheid of wrakingsgrond bestaat. ${ }^{173}$ Benevens deze redenen om zich als rechter te onthouden van een zaak, vereist de plichtenleer van de rechter ook dat hij zich zou onthouden in andere situaties die zulks vereisen om elke indruk van partijdigheid of afhankelijkheid uit te sluiten (bijvoorbeeld wanneer de rechter in zijn privéleven heeft gecontracteerd met een procespartij). ${ }^{174}$ Wanneer

I67 Zie F. Kuty, L'impartialité du juge en procédure pénale. De la confiance décrétée à la confiance justifiée, Brussel, Larcier, 2005, 208 en B. Allemeersch, De naakte grijsaard. Over de rechter en zijn persoonlijke kennis(sen), Antwerpen, Intersentia, 2009, nr. I4, 8.

I68 Zie bijvoorbeeld Cass. I4 februari I977, Arr.Cass. I977, 657, Cass. I juni I999, Arr.Cass. I999, nr. 323 en Cass. 5 mei 2010, AR P.10.0633.F, onuitg.

I69 Cass. I8 februari 2003, JT 2005, 267, met noot F. Kuty. In een later arrest werd echter geoordeeld dat de onderzoeksrechter die in een parlementaire onderzoekscommissie getuigt over een dossier dat bij hem in onderzoek is, twijfels kan opwekken omtrent zijn onpartijdigheid (Cass. 7 april 2004, Arr.Cass. 2004, 615, JT 2004, 54I, met noot O. Klees, JLMB 2004, I365 en Rev.dr.pén. 2004, 1070).

I70 Cass. I4 februari 1977, Arr.Cass. I977, 657.

I7I Zie over de problemen die de wetenschappelijke activiteit van een magistraat kan stellen E. Krings, 'Plichten en rechten van de leden van de rechterlijke macht', Openingsrede Hof van Cassatie, I september I988, RW I988-89, I69-I82, nrs. 28-30. Zie tevens P. Martens, 'La tyrannie de l'apparence', noot onder EHRM 22 februari I996, RTDH I996, 652 en F. Tulkens en S. Van Drooghenbroeck, 'La double vie du juge est-elle compatible avec son impartialité?', in X., Liber Amicorum Paul Martens. L'humanisme dans la résolution des conflits. Utopie ou réalité?, Brussel, Larcier, 2007, 485509, inzonderheid 492-495. Zie tevens Cass. I5 oktober 20I0, R.W. 20I0-II, 745, P\&B 20II, 28 en E. Brewaeys, 'Magistraten mogen schrijven, maar wel gematigd en genuanceerd', Juristenkrant 27 oktober 20I0, 8.

I72 GwH I3 oktober 2009, nr. I57/2009, A.GrwH 2009, 2I6I, NJW 2009, 809, met noot F. Judo, RW 2009-IO, 598, JT 20II, 438 en JLMB 20I0, 4.

I73 Cass. 2 mei I984, Arr.Cass. I983-84, II39, Pas. I984, I, I074 en RW I984-85, I873. Zie ook Cass. 23 juni 2000, Arr.Cass. 2000, II98. Wat de wrakingsgronden betreft, is de verplichting zich te onthouden overigens voorzien bij wet (art. 83I Ger.W.).

I74 Zie voor een aantal andere voorbeeldsituaties X. De Riemaecker en G. Londers, 'Deontologie en tucht', in X., Statuut en deontologie van de magistraat, Brugge, Die Keure, 2000, 328. 
dergelijke situaties zich voordoen, moet de rechter zich verschonen of 'recuseren' en de berechting overlaten aan een collega-magistraat. De beslissing om zich in die gevallen al dan niet van de zaak te onttrekken, komt aan de rechter zelf toe.

Magistraten mogen zich in beginsel zoals iedere burger bij een vereniging aansluiten. Zo wordt aanvaard dat een magistraat lid mag zijn van een politieke partij ${ }^{175}$ en hiertoe een ledenbijdrage mag betalen, voor zover hij uiteraard geen activiteiten uitoefent die onverenigbaar zouden zijn met zijn ambt, zoals de deelname aan politieke verkiezingscampagnes. ${ }^{176}$ Niettemin blijkt uit de rechtspraak van het EHRM dat het politiek engagement van een rechter wel aanleiding kan geven tot een schending van het (objectieve) onpartijdigheidsvereiste, ${ }^{177}$ al zal de loutere politieke sympathie van een rechter op zich niet volstaan om een gewettigde vrees van partijdigheid te wekken. ${ }^{17}$ Gezegd wordt ook dat de magistraat niet het verbod kan opgelegd worden om lid te zijn van een loge, ${ }^{179}$ van een liefdadigheidsclub of van godsdienstige verenigingen, ${ }^{180}$ al wordt daar wel soms aan toegevoegd dat de statutaire doelstellingen van deze vereniging de door de magistraat afgelegde eed (trouw aan de Koning, gehoorzaamheid aan de Grondwet en aan de wetten van het Belgisch volk) niet mogen aantasten, bijvoorbeeld door toe te treden tot een partij die zou pleiten voor aantastingen van de fundamentele mensenrechten zoals erkend in de internationale verdragen die door België werden gesloten. ${ }^{\text {I8r }}$ Waar het een rechter

I75 M. Sterkens, 'Een transparant en onpartijdig rechter', in F. Deruyck, M. De Swaef, J. Rozie, M. Rozie, Ph. Traest en R. Verstraeten (eds.), De wet voorbij. Liber Amicorum Luc Huybrechts, Antwerpen, Intersentia, 2010, 374 .

I76 X. De Riemaecker en G. Londers, 'Deontologie en tucht', in X., Statuut en deontologie van de magistraat, Brugge, Die Keure, 2000, 368.

I77 Zie EHRM 25 november I993, Holm t. Zweden, \$30 (met betrekking tot een jury waarvan vijf van de negen leden lid waren van een politieke partij terwijl het een klacht betrof tegen een auteur en een uitgeverij en vaststond dat de auteur bij dezelfde partij huisideoloog was geweest en bovendien de uitgeverij in kwestie werd gecontroleerd door die partij) en EHRM 6 januari 20I0, Vera Fernández-Huidobro t. Spanje, SII5-I30 (met betrekking tot een onderzoeksrechter die een tijdje een politieke functie had uitgeoefend en vervolgens weer onderzoeksrechter werd). Op zich is het echter niet verboden dat bijvoorbeeld een gewezen parlementslid rechter wordt (EHRM 22 juni 2004, Pabla Ky t. Finland, \$29). Ook het Grondwettelijk Hof wees er reeds op dat een opdracht verricht in het kader van het vroegere mandaat als parlementslid op zich niet kan volstaan om te besluiten tot een schijn van partijdigheid van een voor het leven benoemde rechter wiens onafhankelijkheid door tal van wettelijke bepalingen wordt gewaarborgd (GwH I3 oktober 2009, nr. I57/2009, overweging B.7.4, A.GrwH 2009, afl. 4, 2I6I, NJW 2009, afl. 2II, 809, met noot F. Judo, RW 2009-Io, 598, JT 20II, 438 en JLMB 20I0, 4).

I78 Zie bijvoorbeeld EHRM 28 januari 2003, M.D.U. t. Italië en EHRM 26 augustus 2003, Filippini t. San Marino. Volgens de Raad van State kristalliseert een politieke partij de gedachtestromingen over een veelheid aan vraagstukken die in de samenleving bestaan en mag uit de voorkeur voor een partij niet automatisch worden afgeleid dat de betrokkene het eens is met ieder antwoord van die partij op al die vragen (R.v.St. 22 maart 2007, nr. I69.3I4).

I79 Zie over deze problematiek ook EHRM I5 juni 2000, Salaman t. Verenigd Koninkrijk, waarin gesteld werd dat het loutere lidmaatschap van een loge geen gerechtvaardigde twijfels kan opwekken omtrent de objectieve onpartijdigheid van een magistraat, aangezien men ervan mag uitgaan dat hij zijn eed als magistraat zal zal stellen boven om het even welke sociale verplichting.

I80 H. Botson, 'La magistrature et les libertés constitutionnelles', JT I95I, 97.

I8I X. De Riemaecker en G. Londers, 'Deontologie en tucht', in X., Statuut en deontologie van de magistraat, Brugge, Die Keure, 2000, 368. 
niet kan worden verboden om lid te zijn van een politieke partij of van een loge of een godsdienstige vereniging, kan het in het licht van het neutraliteitsvereiste uiteraard geen kwaad dat hij dat niet is. In sommige (weliswaar eerder uitzonderlijke) gevallen kan het zich voordoen dat het wegens de aard van de zaak of wegens de persoon van een procespartij wenselijk is dat beslist wordt door een of meer rechters waarvan bekend is dat zij geen band vertonen met pakweg een politieke partij (bijvoorbeeld bij processen tegen een andere politieke partij of leden ervan) of met een levensbeschouwelijke of religieuze instelling (bijvoorbeeld bij processen tegen een dergelijke instelling). Ook al mag aangenomen worden dat een rechter die wel een dergelijke band heeft, dat van zich kan afzetten en toch objectief kan oordelen, is het voor de perceptie bij de rechtsonderhorigen en de maatschappij in het algemeen beter dat in die uitzonderlijke gevallen beslist wordt door een of meer rechters wier neutraliteit op dat vlak helemaal niet ter discussie kan worden gesteld, ook al komt de rechtsgeldigheid van de beslissing op juridisch vlak niet noodzakelijk in het gedrang omdat de drempel van wat als problematisch ervaren wordt in het licht van het objectieve onpartijdigheidsvereiste daarmee niet automatisch overschreden is. Het is daarom handig dat een magistratenkorps ook rechters bevat die (door de partijen of de media) niet in een vakje te plaatsen zijn dat zou kunnen overeenstemmen met wat in het geding aan de orde is.

\title{
III Mogelijkheden tot herstel en mogelijke gevolgen van het gebrek aan neutraliteit
}

\author{
A Mogelijkheden tot herstel van het gebrek aan neutraliteit \\ $1 \quad$ Wraking
}

Wraking is het recht dat de wet aan een partij geeft om te weigeren te worden beoordeeld door een lid van het gerecht waarbij de zaak aanhangig is. ${ }^{182}$ Een partij die vreemd is aan de zaak kan derhalve geen wrakingsverzoek neerleggen. ${ }^{183}$ De wrakingsgronden zijn limitatief ${ }^{184}$ opgesomd in het Gerechtelijk Wetboek, waar eveneens de procedure tot wraking is omschreven ${ }^{185}$ Artikel 828 Ger.W. luidt als volgt:

'Iedere rechter kan worden gewraakt om de volgende redenen:

$\mathrm{I}^{\circ}$ wegens wettige verdenking;

$2^{\circ}$ indien de rechter of zijn echtgenoot persoonlijk belang bij het geschil heeft;

I82 Cass. 24 december I993, Arr.Cass. I993, III7; Cass. Io december 2003, Arr.Cass. 2003, nr. 638.

I83 Zie Cass. Io december 2003, JT 2003, 883 en Pas. 2003, I, 638; Cass. I6 oktober 2003, Pas. 2003, I, 503.

I84 Cass. 20 augustus I975, Arr.Cass. I975, II86; Cass. 23 juli 2002, TBBR 2003, 605; Cass. I9 november 2003, Pas. 2003, I, 581. Zie ook Cass. 24 november 1994, Arr.Cass. I994, Ior6 en RW I995-96, 86 en Cass. 28 januari 2004, Pas. 2004, I, 50.

I85 Zie de artikelen 828-847 Ger.W., eveneens van toepassing in strafzaken (Cass. 6 september I977, Arr.Cass. 1978, 24). 
$3^{\circ}$ indien de rechter of zijn echtgenoot bloed- of aanverwant van de partijen of van een hunner in de rechte lijn is, of in de zijlijn tot in de vierde graad, of indien de rechter bloed- of aanverwant in de voormelde graad is van de echtgenoot van een der partijen; $4^{\circ}$ indien de rechter, zijn echtgenoot, hun bloed- of aanverwanten in de opgaande en de nederdalende lijn, een geschil hebben over een gelijksoortige aangelegenheid als waarover de partijen in geschil zijn;

$5^{\circ}$ indien in hun naam een geding aanhangig is voor een rechtbank waarin een van de partijen rechter is; indien zij schuldeiser of schuldenaar van een der partijen zijn; $6^{\circ}$ indien een crimineel geding is gevoerd tussen hen en een van de partijen, of hun echtgenoten, bloed- of aanverwanten in de rechte lijn;

$7^{\circ}$ indien er een burgerlijk geding hangende is tussen de rechter, zijn echtgenoot, hun bloedverwanten in de opgaande en de nederdalende lijn of hun aanverwanten in dezelfde lijn, en een van de partijen, en dat geding, indien het door de partij is ingesteld, begonnen is vóór het geding waarin de wraking wordt voorgedragen; indien dat geding, ingeval het afgehandeld is, binnen zes maanden vóór de wraking afgedaan is; $8^{\circ}$ indien de rechter voogd, toeziende voogd of curator, voorlopig bewindvoerder of gerechtelijk raadsman, begiftigde of vermoedelijk erfgenaam, meester of vennoot van een der partijen is; indien hij beheerder of commissaris is van enigerlei instelling, vennootschap of vereniging die partij is in het geding; indien een der partijen zijn begiftigde of vermoedelijke erfgenaam is;

$9^{\circ}$ indien de rechter raad gegeven, gepleit of geschreven heeft over het geschil; indien hij daarvan vroeger kennis heeft genomen als rechter of als scheidsrechter, behalve indien hij in dezelfde aanleg:

I. heeft medegewerkt aan een vonnis of een uitspraak alvorens recht te doen;

2. na uitspraak te hebben gedaan bij verstek, van de zaak kennis neemt op verzet;

3. na uitspraak te hebben gedaan op een voorziening, later van dezelfde zaak kennis neemt in verenigde kamers;

$10^{\circ}$ indien de rechter heeft deelgenomen aan een vonnis in eerste aanleg en hij van het geschil kennis neemt in hoger beroep;

$\mathrm{II}^{\circ}$ indien hij als getuige is opgetreden; indien hij, sedert de aanvang van het geding, door een partij op haar kosten ontvangen is of geschenken van haar heeft aangenomen;

$\mathrm{I} 2^{\circ}$ indien er tussen hem en een van de partijen een hoge graad van vijandschap bestaat; indien er zijnerzijds aanrandingen, mondelinge of schriftelijke beledigingen of bedreigingen hebben plaatsgehad sinds de aanleg van het geding of binnen zes maanden vóór de voordracht van de wraking.'

Over deze wrakingsgronden is heel wat rechtspraak voorhanden, zodat een exhaustief overzicht hier niet kan gegeven worden. ${ }^{186}$ Wel kan een aantal voorbeelden gegeven worden van feiten die reeds aanleiding gaven tot wraking. ${ }^{87}$

I86 Zie voor een uitgebreide bespreking van de wrakingsgronden F. Kuty, L'impartialité du juge en procédure pénale. De la confiance décrétée à la confiance justifiée, Brussel, Larcier, 2005, I9I-2I3.

I87 Zie evenwel ook supra betreffende de deontologische verplichtingen van de rechter en de aldaar gegeven voorbeelden. 
Ongetwijfeld een van de meest ophefmakende beslissingen op het vlak van wraking, was de beslissing van het Hof van Cassatie om het dossier Dutroux te onttrekken aan onderzoeksrechter Connerotte, beter bekend als het zogenoemde 'spaghettiarrest'. ${ }^{188}$ De feiten die aan deze beslissing vooraf gingen kunnen worden geschetst als volgt. ${ }^{189}$ De onderzoeksrechter had tijdens een feestje voor al diegenen die op een of andere manier hadden bijgedragen aan de redding van twee slachtoffers in aanwezigheid van die slachtoffers een bord spaghetti gegeten en een geschenk (een vulpen) aanvaard. Nadat hiervan onder meer foto's verschenen in de pers, werd de onpartijdigheid van de onderzoeksrechter door de raadsman van Dutroux ter discussie gesteld. Het arrest van het Hof van Cassatie bevatte de volgende overwegingen:

'Overwegende dat de onpartijdigheid van de rechter een fundamentele regel is van de rechterlijke inrichting; dat zij samen met het beginsel van de onafhankelijkheid van de rechters ten aanzien van de andere Machten de grondslag zelf is, niet alleen van de grondwettelijke bepalingen die het bestaan van de rechterlijke macht regelen, maar van elke democratische Staat; dat zulks voor de rechtsonderhorigen de waarborg inhoudt dat de rechters de wet op een gelijke wijze zullen toepassen;

Overwegende dat de onpartijdigheid van de onderzoeksrechter dwingend vereist dat hij volledig onafhankelijk staat tegenover de partijen, zodat hij niet de schijn van partijdigheid kan wekken bij het onderzoek van de feiten à charge of à décharge; dat de onderzoeksrechter nooit ophoudt een rechter te zijn die geen schijn van partijdigheid mag wekken bij de partijen of bij de publieke opinie; dat geen enkele omstandigheid, hoe uitzonderlijk ook, hem van die verplichting ontslaat;'

Het Hof van Cassatie besloot dat de onderzoeksrechter die door een partij op haar kosten is ontvangen of van haar geschenken heeft aangenomen en aldus zijn sympathie voor die partij heeft geuit, in de onmogelijkheid verkeert haar zaak te behandelen, zonder bij de andere partijen, meer bepaald de verdachten, en bij derden verdenking te wekken aangaande zijn geschiktheid om zijn opdracht op een objectieve en onpartijdige wijze te vervullen. Het Hof van Cassatie paste daarmee consequent de beginselen inzake de vereisten van onpartijdigheid in hoofde van de onderzoeksrechter toe, wat evenwel tot felle kritiek leidde bij de publieke opinie.

Er wordt ook tot wraking besloten wanneer de voorzitter van het hof van assisen bewoordingen gebruikt die gewettigde verdenking kunnen wekken aangaande de

I88 Cass. I4 oktober I996, Arr.Cass. I996, 379, AJT-Dossier I996-97, met noot J. Rozie, Jaarboek Mensenrechten I996-97, 37I, JT 1996, 670, JLMB I997, I75, met noot M. Uyttendaele en R. Witmeur, Journ.Proc. I996, afl. 313, 25 en Rev.dr.pén. I997, 470, met noot A. Jacobs. Zie over dit arrest onder meer ook W. Van Gerven, 'Creatieve rechtspraak', RW I997-98, 2I4-2I7 en F. Delpérée, 'Quelques propos sur la justice et la politique', JT r997, 69.

I89 Zie M. Adams, 'Vrijheid en verantwoordelijkheid van de rechterlijke macht', in X., Verantwoordelijkheid en recht, Mechelen, Kluwer, 2008, nrs. 9-I2, I38-I40 en J. Messine, 'De quelques suites de l'affaire Dutroux sur le pouvoir judiciaire et sur l'indépendance des juges', in X., Liber Amicorum Henri-D. Bosly, Brussel, La Charte, 2009, 239-246. 
geschiktheid van die magistraat om op onpartijdige en onafhankelijke wijze uitspraak te doen, bijvoorbeeld wanneer hij de raadsman van de verdediging heeft gelast te zwijgen en hem heeft gezegd ermee op te houden 'de aap uit te hangen'. ${ }^{100}$ Een voorzitter van het hof van assisen mag ook niet een beschuldigde een 'pipo' noemen en tegenover de jury stellen dat de verklaringen van de beschuldigde niet stroken met de waarheid. ${ }^{\text {I9I }}$ Vooral dat laatste was echter doorslaggevend en niet zozeer de door de voorzitter gebruikte term 'pipo'. Er is immers een wereld van verschil tussen het stellen dat een verklaring niet met de waarheid overeenstemt enerzijds, en het vaststellen dat de verklaring niet overeenstemt met andere gegevens uit het strafdossier of met andere verklaringen ter zitting anderzijds. In het eerste geval wordt immers al standpunt ingenomen over de zaak en is er dus sprake van prejugeren. Een strafrechter mag de raadsman van de verdediging ook niet herhaaldelijk onderbreken om hem aan te manen om ter zake te komen en om hem te beletten om relevante passages uit het strafdossier te citeren, omdat de sereniteit van de behandeling van de zaak daardoor in gevaar kan worden gebracht en hieruit een hoge graad van vijandigheid kan worden afgeleid. ${ }^{192}$ Ook de rechter die het vermoeden van onschuld schendt, kan worden gewraakt. De rechter moet er derhalve over waken dat hij niets zegt waaruit blijkt dat zijn mening reeds gevormd is. ${ }^{193}$ Zo werd beslist dat moet worden gewraakt de onderzoeksrechter die in een brief aan de procureur des Konings had geschreven 'de vermoedelijke dader blijft ontkennen'. ${ }^{194}$

Over de wraking wordt beslist door de onmiddellijk hogere instantie (het hof van beroep of het Hof van Cassatie), behoudens voor de magistraten van het Hof van Cassatie of van het Grondwettelijk Hof. In principe worden alle verrichtingen en vonnissen geschorst te rekenen van de dag van de mededeling van het verzoek tot wraking aan de betrokken rechter. ${ }^{195}$ Indien de wraking wordt toegelaten, wordt aan de gewraakte rechter het bevel gegeven zich van de zaak te onthouden. ${ }^{196}$

De verwijzing van de ene rechtbank naar de andere is de handeling waarbij een zaak, die regelmatig voor een rechter is gebracht, aan diens kennisneming wordt onttrokken ten einde te worden verwezen naar een andere door het Hof van Cassatie aangewezen rechter. ${ }^{197}$ Het verschil met de wraking is dat bij een verzoek tot

I9o Cass. 29 oktober 2003, Arr.Cass. 2003, I996 en JT 2003, 746.

I9I Cass. 28 februari 2008, RW 2008-09, 237, met noot A. Vandeplas en NJW 2008, 258, met noot N. Peeters.

I92 Zie Cass. 4 februari I997, Arr.Cass. 1997, I62.

I93 Zie bijvoorbeeld Cass. 22 maart 2002, Arr.Cass. 2002, 855, RW 2004-05, I074 en J.dr.jeun.2002, 6I.

I94 Cass. 23 november 2006, P\&B 2007, 276, JT 2007, 34, met noot B. Dejemeppe en JLMB 2007, 583 , met noot J. Defourny. Een loutere toespeling door een onderzoeksrechter op een mogelijke behandeling van de zaak ten gronde werd evenwel onvoldoende bevonden om een schending van het vermoeden van onschuld aan te nemen (Cass. I9 november 2003, Arr.Cass. 2003, nr. 58I).

I95 Zie art. 837 Ger.W.

I96 Art. 84I, $\mathrm{I}^{\mathrm{e}}$ lid Ger.W.

I97 Cass. 7 april 2005, Arr.Cass. 2005, nr. 2 Io. 
verwijzing van de ene rechtbank naar de andere niet zozeer een enkele rechter wordt bekritiseerd, maar wel de rechtbank in haar geheel. Om een verwijzing te bekomen, moet dus vastgesteld worden dat men van alle rechters van de rechtbank mag zeggen dat ze niet in staat zijn om in de zaak op onafhankelijke en onpartijdige wijze uitspraak te doen ${ }^{198}$ of dat er bij derden of de openbare opinie een gewettigde twijfel zou worden gewekt aangaande hun geschiktheid om de zaak op zodanige wijze te behandelen. ${ }^{199}$ Een verwijzing naar een andere rechtbank kan door het openbaar ministerie worden gevraagd om redenen van openbare veiligheid ${ }^{200}$ of op grond van gewettigde verdenking. Ook belanghebbende partijen kunnen de verwijzing vragen, maar dan enkel op grond van gewettigde verdenking. ${ }^{201}$ De zaak waarvan de verwijzing wordt gevraagd, kan een zaak zijn die aanhangig is bij onder meer een vonnisgerecht (bijvoorbeeld bij een correctionele rechtbank, een hof van beroep of een hof van assisen), bij een onderzoeksgerecht of bij een onderzoeksrechter. ${ }^{202}$ In dat laatste geval zal een verwijzing echter enkel kunnen toegestaan worden om redenen die niet uitsluitend de persoon van de onderzoeksrechter betreffen maar de gehele rechtbank (bijvoorbeeld omdat de inverdenkinggestelde de zoon is van een rechter bij diezelfde rechtbank), ${ }^{203}$ wat vroeger anders was. ${ }^{204}$

Er bestaat zeer omstandige rechtspraak over wat wel en wat niet kan leiden tot een verwijzing van de ene rechtbank naar de andere op grond van gewettigde verdenking. ${ }^{205}$ In strafzaken werd bijvoorbeeld reeds besloten tot verwijzing naar een andere rechtbank omdat in een zaak hangende voor het hof van beroep een van de beklaagden procureur des Konings was in hetzelfde rechtsgebied, ${ }^{206}$ of omdat een van de beklaagden de zoon was van een magistraat van de rechtbank en de vader zelf als civielrechtelijke aansprakelijke werd opgeroepen, ${ }^{207}$ omdat de onderzoeksrechter werd belast met een onderzoek tegen de zoon van een rechter in dezelfde rechtbank ${ }^{208}$ of tegen de zoon van de voorzitter van de rechtbank, ${ }^{209}$ omdat de burgerlijke partij procureur des Konings was bij de rechtbank die over een zaak moest

I98 Zie bijvoorbeeld Cass. I9 april I994, Arr.Cass. I994, nr. I87.

I99 Zie bijvoorbeeld Cass. 7 mei I986, Arr.Cass. I985-86, nr. 549.

200 Het betreft dan omstandigheden die van dien aard zijn dat men op de plaats waar het gerecht zetelt onlusten of wanordelijkheden vreest. Zie voor enkele voorbeelden uit de ige eeuw en de periode van de Eerste Wereldoorlog R. Declercq, 'Verwijzing van de ene rechtbank naar de andere', in Comm.Straf., Mechelen, Kluwer, nr. 6, 4-5 (afl. 54). Dergelijke omstandigheden zullen zich weliswaar in de hedendaagse maatschappij niet snel meer voordoen.

201 Zie art. 542 Sv.

202 Zie voor verwijzingen en andere voorbeelden R. Declercq, Beginselen van Strafrechtspleging, Mechelen, Kluwer, 2007 (4e ed.), nr. 3702, I586-I587.

203 Cass. 5 april 2005, Arr.Cass. 2005, nr. 199.

204 Art. 542, $\mathrm{I}^{\mathrm{e}}$ lid Sv. bevatte vroeger nog de mogelijkheid om de zaak te verwijzen van de ene onderzoeksrechter naar de andere. Die mogelijkheid werd afgeschaft in 1998.

205 Zie voor een uitvoerig overzicht R. Declercq, 'Verwijzing van de ene rechtbank naar de andere', in Comm.Straf., Mechelen, Kluwer, nrs. 57-64, 26-35 (afl. 54).

206 Cass. 23 maart I983, Arr.Cass. I982-83, nr. 4I2.

207 Cass. Io januari 1972, Arr.Cass. I972, 452.

208 Cass. I7 januari I972, Arr.Cass. I972, 482 en Cass. I7 juni 1974, Arr.Cass. I974, II33.

209 Cass. I7 juni ig86, Arr.Cass. I985-86, nr. 655. 
beslissen $^{210}$ of omdat de burgerlijke partij de vader was van een rechter in dezelfde rechtbank. ${ }^{211}$ Er wordt ook verwezen naar een andere rechtbank als een rechtbank wegens de omstandigheden niet bij machte is een zetel samen te stellen, ${ }^{212}$ bijvoorbeeld wanneer alle rechters van de rechtbank een wettige reden van wraking hebben of zich moeten onthouden. ${ }^{213}$ Wanneer verwezen wordt naar een andere rechter, beslist het Hof van Cassatie zelf naar welke rechter. De partijen hebben zich met die keuze niet in te laten. ${ }^{214}$ Meestal wordt verwezen naar een andere rechtbank in hetzelfde rechtsgebied, ${ }^{215}$ maar er kunnen ook redenen bestaan om te verwijzen naar een rechtbank in een ander rechtsgebied. ${ }^{216}$

\section{B Andere mogelijke gevolgen van het gebrek aan neutraliteit \\ $1 \quad$ Tuchtprocedure}

Zoals hoger aangegeven, moet de (straf)rechter rekening houden met deontologische verplichtingen die onder meer tot doel hebben zijn neutraliteit te verzekeren. Het spreekt voor zich dat in zoverre deze deontologische verplichtingen niet worden nagekomen, een tuchtprocedure tot de mogelijkheden behoort. De wet maakt zelfs expliciet melding van de tuchtsanctie indien een rechter een zaak behandelt niettegenstaande hij echtgenoot, bloed- of aanverwant in de rechte lijn of in de tweede graad in de zijlijn is van de advocaat of van de gemachtigde van een der partijen. ${ }^{217}$

De tuchtvordering wordt meestal ingesteld door de korpsoversten ${ }^{218}$ die dan bevoegd zijn om een lichte tuchtstraf (een waarschuwing of berisping) op te leggen. ${ }^{219}$ Zware tuchtstraffen ${ }^{220}$ kunnen worden opgelegd, al naar gelang het geval, door de eerste kamer van het hof van beroep of van het Hof van Cassatie of door de algemene vergadering van dat Hof. ${ }^{221}$

\footnotetext{
2 Io Cass. 8 mei I99I, Arr.Cass. I990-9I, nr. 464.

2 II Cass. ig februari i986, Arr.Cass. I985-86, nr. 400.

212 Cass. 7 oktober i946, Pas. I946, I, 346.

213 Cass. 7 januari 1974 , Arr.Cass. I974, 503.

2 I4 Cass. 4 juni 1877, Pas. I877, I, 246.

2 I5 R. Declercq, 'Verwijzing van de ene rechtbank naar de andere', in Comm.Straf., Mechelen, Kluwer, nr. 65, 35 (afl. 54).

2i6 Zie bijv. Cass. 3 september 1986, Arr.Cass. I986-87, nr. 8 en Cass. 6 mei 1994, Arr.Cass. I994, nr. 221 .

217 Art. 304 Ger.W.

2I8 Zie de opsomming in art. 4IO, §I, $\mathrm{I}^{\circ} \mathrm{Ger} . W$.

2 I9 P. Maffei, 'Tuchtrecht voor magistraten en EVRM', in F. Deruyck, M. De Swaef, J. Rozie, M. Rozie, Ph. Traest en R. Verstraeten (eds.), De wet voorbij. Liber Amicorum Luc Huybrechts, Antwerpen, Intersentia, 20I0, nr. 28, 269. Zie art. 4I2, §I Ger.W.

220 Zie voor een opsomming art. 405, §2 Ger.W.

22I Zie art. 4I2, \$2 Ger.W.
} 
De advies- en onderzoekscommissies van de Hoge Raad voor de Justitie ontvangen klachten over de werking van de rechterlijke orde en verzekeren de opvolging ervan. ${ }^{222}$ Elke burger kan derhalve een klacht indienen bij de Hoge Raad voor de Justitie als hij daar redenen tot zou hebben. Niet alle klachten worden echter behandeld. Zo mag de klacht niet behoren tot de strafrechtelijke of tuchtrechtelijke bevoegdheid van andere overheden of mag de klacht geen betrekking hebben op de inhoud van een rechterlijke beslissing of mag het doel ervan niet via een gewoon of buitengewoon rechtsmiddel kunnen worden bereikt. ${ }^{223}$ Dat betekent dat klachten die betrekking hebben op een vermeend gebrek aan neutraliteit doorgaans niet mogelijk zijn omdat er nog een rechtsmiddel kan worden aangewend waarbij de onpartijdigheid kan worden aangevoerd om een hervorming of vernietiging van de beslissing te bekomen, tenzij het probleem zich zou hebben voorgedaan op het niveau van het Hof van Cassatie of het Grondwettelijk Hof of de gronden van de klacht de betrokkene pas ter kennis zijn gekomen nadat de zaak al kracht van gewijsde heeft verkregen, en zelfs dan zal moeten nagegaan worden of de klacht niet behoort tot de strafrechtelijke of tuchtrechtelijke bevoegdheid van andere overheden. Bij gegronde klachten kunnen de advies- en onderzoekscommissies aanbevelingen doen ter oplossing van het gestelde probleem en voorstellen ter verbetering van de algemene werking van de rechterlijke orde formuleren ten behoeve van de betrokken instanties en de minister van Justitie. ${ }^{24}$

\section{Mogelijke kwetsbaarheden en bedreigingen}

\section{A Ten aanzien van de objectieve neutraliteit}

$1 \quad$ Het gebruik van plaatsvervangende rechters en raadsheren

Naast beroepsmagistraten zijn er ook plaatsvervangende rechters en raadsheren die benoemd worden om verhinderde magistraten tijdelijk te vervangen of om zitting te nemen wanneer de bezetting niet volstaat om de zetel samen te stellen. ${ }^{25} \mathrm{Het}$ betreft personen die doorgaans als hoofdactiviteit het beroep van advocaat, notaris of universiteitsprofessor uitoefenen. ${ }^{226}$ Sommige plaatsvervangende magistraten zetelen vrij frequent, bijvoorbeeld op wekelijkse basis. In 2004 waren er in België,

222 Zie art. 259bis-I5, §I Ger.W.

223 Zie art. 259bis-I5, \$3 Ger.W.

224 Art. 259bis-I5, \$6, 2e lid Ger.W.

225 Zie de artikelen 7I, 87 en I02 Ger.W.

226 J. Laenens, K. Broeckx, D. Scheers en P. Thiriar, Handboek gerechtelijk recht, Antwerpen, Intersentia, 2008, nr. 355, I85. 
weliswaar niet alleen in strafzaken, meer dan 2.000 plaatsvervangende magistraten actief voor I.555 beroepsrechters en 8I2 professionele parketmagistraten. ${ }^{227}$

Het werken met plaatsvervangende magistraten kan delicaat zijn, omdat bij het publiek de schijn van partijdigheid kan ontstaan wanneer bijvoorbeeld een advocaat de ene dag een zaak komt bepleiten voor een rechtbank en hij op een andere dag deel uitmaakt van die rechtbank en mee moet beslissen over de zaken die door zijn confraters worden bepleit. Ook het toenmalige Arbitragehof wees er reeds op dat de aanwezigheid van advocaten in bepaalde kamers van het hof van beroep zou kunnen leiden tot een functieverwarring tussen de rechter en de advocaat en tot belangenverstrengeling, wat twijfels zou kunnen oproepen omtrent de onafhankelijkheid en onpartijdigheid van het rechtscollege, alhoewel er werd aan toegevoegd dat laatstgenoemd risico aanzienlijk is getemperd door het toezicht uitgeoefend door het Hof van Cassatie op de rechtspraak. ${ }^{228}$ De Hoge Raad voor de Justitie gaf daarom reeds enkele aanbevelingen in een ambtshalve advies van 26 april 2006. ${ }^{229}$ Er werd tevens gepleit voor een studie die de noodzakelijkheid en de opportuniteit van het systeem onderzoekt. Een dergelijke studie lijkt inderdaad aangewezen.

Ook de samenstelling van een rechtscollege kan de onafhankelijkheid en onpartijdigheid van de strafrechter in het gedrang brengen wanneer de beïnvloeding van de eindbeslissing een motief bij de samenstelling van het college of de aanduiding van de rechter zou zijn. De wijze waarop een rechter wordt aangewezen in een zaak, kan immers een schijn van afhankelijkheid en partijdigheid doen ontstaan. ${ }^{230}$ In de zaak Erdal verduidelijkte het Hof van Cassatie dat de aanwijzing van een rechter met toepassing van artikel 98 van het Gerechtelijk Wetboek ${ }^{23}$ geen middel mag zijn om de samenstelling van de zetel voor de behandeling van een welbepaalde zaak te beïnvloeden en dat de omstandigheden waarin die aanwijzing gebeurt, evenmin van aard mogen zijn bij de partijen en bij derden een schijn van partijdigheid

227 R. Boone, 'Hoge Raad stelt plaatsvervangende rechters in vraag', Juristenkrant io mei 2006, afl. I29, 6. Het is echter onmogelijk om het werkelijke percentage van de activiteit van de plaatsvervangende rechters te schatten ten opzichte van die van de beroepsrechters.

228 Arbitragehof 3 maart I999, nr. 29/99, overweging B.5.8, AA I999, 32I, RW I999-00, 43, Jaarboek Mensenrechten, I998-oo, 238, JT I999, 343 en TBP 1999, 685.

229 Ambtshalve advies over de plaatsvervangende rechters, 26 april 2006, I6 p., de tekst kan geraadpleegd worden via volgende link: www.csj.be/doc/advice/Avis-26-04-06.pdf.

230 R. Clayton en H. Tomlinson, Fair Trial Rights, Oxford, University Press, 200I, Io8.

23I Deze bepaling voorziet in de mogelijkheid dat de eerste voorzitter op vordering of op advies van de procureur-generaal tijdelijk een rechter uit zijn rechtsgebied aanwijst om zijn ambt bijkomend en voor een bepaalde termijn uit te oefenen in een andere rechtbank van eerste aanleg binnen het rechtsgebied. Deze bepaling verbiedt niet dat de tijdelijke aanwijzing van een rechter gebeurt voor een welbepaalde zaak en bovendien komt de beoordeling van de wenselijkheid van de aanwijzing enkel aan de eerste voorzitter toe (G. Maes, 'De samenstelling van de zetel van de rechtbank in het licht van de onafhankelijkheid en onpartijdigheid van de strafrechter', noot onder Cass. I9 april 2007, RW 2006-07, I726). 
of van afhankelijkheid te doen rijzen. ${ }^{232}$ In deze zaak werd de beslissing in eerste aanleg genomen door de correctionele rechtbank te Brugge, die voor de gelegenheid werd voorgezeten door een rechter uit een ander arrondissement. De eerste voorzitter van het hof van beroep had zijn verzoek aan de procureur-generaal om advies over de aanwijzing van die rechter gemotiveerd met verwijzing naar twee elementen. Vooreerst werd gewezen op het feit dat de federale procureur het proces had omschreven als erg geladen. Daarnaast werd gewezen op het feit dat de Brugse vrouwelijke strafrechter die de zaak normaliter zou hebben voorgezeten, zich beter geruggensteund zou voelen door een mannelijke ervaren strafrechter. Het Hof van Cassatie was van oordeel dat deze verantwoording bij de justitiabele de indruk kan wekken dat de samenstelling van de zetel werd beïnvloed in functie van het dossier. Daardoor leek het er immers op dat de aanwijzing van de concrete rechter, en los van diens persoonlijke onpartijdigheid die op geen enkel ogenblik ter discussie werd gesteld, verklaard en bepaald werd door het concreet voorliggende dossier, en dat de schijn kan ontstaan dat dit de uitkomst van de beoordeling heeft beïnvloed. ${ }^{23}$ De procureur-generaal had overigens negatief geadviseerd, wat volgens het Hof van Cassatie de schijn van onpartijdigheid alleen maar heeft versterkt. De zaak werd nadien nog behandeld in graad van beroep, waar er geen sprake was van een speciale samenstelling. Toch heeft dat het probleem van de schijn van partijdigheid in eerste aanleg niet kunnen oplossen, omdat het hof van beroep volgens het Hof van Cassatie ten onrechte had geoordeeld dat de samenstelling van de zetel in eerste aanleg regelmatig was in de zin van de artikelen 6.I EVRM en I4.I IVBPR en het beroepen vonnis derhalve niet was vernietigd. Het Hof van Cassatie merkt op dat hierdoor bij de beklaagden meteen een schijn van partijdigheid en afhankelijkheid van de appelrechters zelf kan rijzen. Uit deze rechtspraak volgt niet dat het niet langer mogelijk zou zijn dat een tijdelijke aanwijzing zou gebeuren voor een welbepaalde zaak. Zulks kan immers gerechtvaardigd zijn door de behoeften van de dienst en het feit dat bijvoorbeeld een of meer plaatsen van rechters openstaan in de verzoekende rechtbank. Maar bij dergelijke beslissingen moet wel omzichtig te werk worden gegaan, zodat geen schijn van partijdigheid ontstaat bij de beklaagde dat de aanwijzing gebeurt om de zaak te beïnvloeden.

Hierbij aansluitend kan ook verwezen worden naar de mogelijkheid die in België bestaat voor het openbaar ministerie en de beklaagde om een zaak die normaliter behandeld wordt door een alleenzetelend rechter te doen verwijzen naar een collegiale kamer. ${ }^{234}$ Dat stelsel maakt het in zekere zin mogelijk dat de beklaagde of het openbaar ministerie zelf hun rechter kiezen. Zo kan een verwijzing naar drie rechters gevraagd worden om te ontsnappen aan een rechter die misschien te streng

232 Cass. I9 april 2007, Arr.Cass. 2007, 82I, RW 2006-07, I72I, met noot G. Maes, TBP 2008, 442, TGRTWVR 2007, I92 en T.Strafr. 2007, 376, met noot P. De Hert en J. Millen.

233 G. Maes, 'De samenstelling van de zetel van de rechtbank in het licht van de onafhankelijkheid en onpartijdigheid van de strafrechter', noot onder Cass. I9 april 2007, RW 2006-07, I727.

234 Sommige zaken worden automatisch behandeld door een collegiale kamer (zie art. 92, §I, $4^{\circ}$ Ger.W.). De andere zaken worden in principe behandeld door een kamer met één rechter, tenzij de verwijzing wordt gevraagd naar een kamer met drie rechters (zie art. 9I Ger.W.). 
is, ${ }^{235}$ of indien het verzoek van het openbaar ministerie uitgaat, aan een rechter die te mild is. Dat zou aanleiding kunnen geven tot een schijn van partijdigheid bij rechtsonderhorigen, omdat het van de beslissing van het openbaar ministerie zelf afhangt of gedagvaard wordt voor de ene dan wel de andere kamer. Er werd dan ook reeds gesuggereerd dat het beter zou zijn dat de wet zelf rechtstreeks zou bepalen welke zaken aan een kamer met drie rechters worden toegewezen, zonder dat de partijen daar nog enige zeggenschap in zouden hebben. ${ }^{236}$

De plaats van het openbaar ministerie in de zittingszaal

Soms wordt geopperd dat het openbaar ministerie een bevoorrechte plaats inneemt in de zittingszaal en dat daardoor de schijn van afhankelijkheid of partijdigheid zou worden gewekt bij de beklaagde. De plaats van het openbaar ministerie in de zittingszaal hangt uiteraard samen met de vorm van de strafprocedure en de positie die het openbaar ministerie inneemt binnen het staatsbestel. ${ }^{237}$ Meestal is het openbaar ministerie - vanuit het oogpunt van de beklaagde - gezeten aan de linkerzijkant van de tafel waar de strafrechter plaatsneemt, recht tegenover de griffier die aan de rechterzijkant plaatsneemt. Daardoor is het onderscheid tussen de rechter of rechters enerzijds en het openbaar ministerie en de griffier anderzijds visueel gemakkelijk te maken. In sommige rechtbanken echter, wordt ervoor geopteerd om allen plaats te nemen naast elkaar, dus op één rij. Dat is eigenlijk geen gelukkige keuze, ook al lijkt daardoor niet meteen een probleem te rijzen op het vlak van de schijn van partijdigheid.

In een arrest van het Hof van Cassatie van 27 april 2010 was de vraag aan de orde of de positie van het openbaar ministerie in assisenzaken al dan niet leidt tot een schending van het recht op een eerlijk proces en een aantasting van het vereiste van een onafhankelijke en onpartijdige rechter. De verdediging had aangevoerd dat dit het geval was, omdat het openbaar ministerie een verhoogde plaats innam ten overstaan van de andere partijen en gezeten was aan dezelfde tafel als de beroepsmagistraten en bovendien ook dezelfde toga droeg als de voorzitter van het Hof van assisen. Het Hof van Cassatie was evenwel van oordeel dat de beklaagde of beschuldigde geen afhankelijkheid of partijdigheid van de rechter of de jury mag afleiden uit de enkele omstandigheid dat er een verschil bestaat in plaats en kledij tussen het openbaar ministerie en de verdediging. ${ }^{23} 8$

235 Cf. A. Vandeplas, 'In de ban van de alleenrechtsprekende rechter', RW I985-86, 335.

236 Zie hierover Ph. Traest, 'Enkele bedenkingen over de alleenzetelende rechter in strafzaken', in F. Deruyck, M. De Swaef, J. Rozie, M. Rozie, Ph. Traest en R. Verstraeten (eds.), De wet voorbij. Liber Amicorum Luc Huybrechts, Antwerpen, Intersentia, 2010, 415-428.

237 P. Vanwalleghem, 'Plaats en toga procureur leiden niet tot oneerlijk proces', Juristenkrant 26 mei 20I0, 3 .

238 Cass. 27 april 20I0, AR P.Io.orIg.N, onuitg. 
Wel moet er uiteraard rekening gehouden worden met het geheim van de beraadslaging, ${ }^{239}$ dat met zich brengt dat wanneer de rechters zich in raadkamer terugtrekken om over het vonnis te beslissen, het openbaar ministerie daar niet bij mag zijn. ${ }^{20}$ Wanneer een rechtbank met gesloten deuren zetelt (wat bijvoorbeeld het geval is bij de onderzoeksgerechten), dan is het aangewezen om erop toe te zien dat het openbaar ministerie de zittingszaal verlaat tussen de behandeling van de respectievelijke zaken door, tenzij de behandeling van de volgende zaak onmiddellijk een aanvang kan nemen. Indien dat niet gebeurt, kan bij de verdachte immers de schijn ontstaan dat er over de zaak gepraat wordt, ook al wordt in werkelijkheid over iets anders gesproken omdat de rechters of de raadsheren op dat ogenblik toe zijn aan een korte pauze.

\section{B Ten aanzien van de subjectieve neutraliteit}

$1 \quad$ Het grote gewicht dat aan het vooronderzoek wordt verleend

Zoals hoger besproken, moet de strafrechter de zaak die bij hem aanhangig is onbevangen beoordelen en moet hij daarbij openstaan voor elke mogelijke piste of voor elke eventuele bijkomende onderzoeksmaatregel die de waarheid ten goede zou kunnen komen. In het Belgisch strafprocessuele systeem wordt echter heel erg de nadruk gelegd op het vooronderzoek en gaat derhalve een groot gewicht uit van het strafdossier. De strafrechter die over de grond van de zaak uitspraak moet doen, wordt daarom soms omschreven als een 'verificatierechter'. ${ }^{24}$ Het onmiddellijkheidsbeginsel is daarbij zwaar op de achtergrond komen te staan. ${ }^{242}$ Daardoor ontstaat het risico dat de strafrechter te veel steunt op stukken die werden opgesteld door verbalisanten die misschien niet onbevangen of onpartijdig hebben onderzocht of verhoord. ${ }^{243}$ Zo kan een samenvattend proces-verbaal bijvoorbeeld een enigszins vertekend beeld geven van de waarheid, omdat politieambtenaren nu eenmaal niet in dezelfde mate als rechters stilstaan bij het belang van het onbevangen en onpartijdig zijn en er soms bij het onderzoek ook al eens sprake is van de zogenoemde tunnelvisie. ${ }^{244}$ Het lijkt ook logisch dat politieambtenaren die het misdrijf of de gevolgen ervan gezien hebben, anders tegen de feiten zullen aankijken dan de rechter die er nadien over te oordelen zal hebben. Het vertrekpunt is immers anders: tijdens het vooronderzoek wil men een dader vinden, terwijl bij het onderzoek ter terechtzitting geoordeeld moet worden of de beklaagde die terechtstaat inderdaad

239 Zie over de oorsprong hiervan R. Verstraeten, 'De rechter doet uitspraak', in X., Strafrecht en strafprocesrecht. XXXIIe Postuniversitaire Cyclus Willy Delva, Mechelen, Kluwer, 2006, nr. 9, 4I3-4I4.

240 Art. 768 Ger.W.

$24 \mathrm{I}$ Ch. Van den Wyngaert, Strafrecht en strafprocesrecht in hoofdlijnen, I, Antwerpen, Maklu, 2009 (7e ed.), 585 .

242 Zie hierover B. De Smet, 'Het onmiddellijkheidsbeginsel in het strafproces: een anachronisme of een waarborg voor een kwalitatief goede rechtspleging?', RW I996-97, 65-76.

243 Wat dat laatste betreft is er uiteraard de belangrijke impact van de door het EHRM opgelegde verplichting om te voorzien in het recht op bijstand van een raadsman bij het verhoor.

244 Zie over dit fenomeen E. Rassin, Waarom ik altijd gelijk heb. Over tunnelvisie, 2007, Schiedam, Scriptum, I73 p. 
de dader is. Alhoewel een eventueel gebrek aan neutraliteit of onbevangenheid bij de opsporingsambtenaren niet impliceert dat er sprake is van een gebrek aan neutraliteit bij de strafrechter (en in dit preadvies als dusdanig dus niet te sprake zou hoeven te komen), mag er toch op gewezen worden dat het belang van de 'open geest' van de strafrechter hierdoor nogmaals wordt onderstreept. Dat veronderstelt dat de rechter bereid is alles wat hem wordt voorgelegd ter discussie te stellen en dat hij eventuele verzoeken om getuigen te horen ter zitting of om welbepaalde onderzoeksdaden te doen stellen met de nodige zorg moet beoordelen. Wanneer de rechter enkel schriftelijke bewijsgegevens aan zijn oordeel ten grondslag legt, bestaat het risico immers dat hij een mogelijk vertekende weergave van de feiten niet op het spoor komt. ${ }^{245}$ Een voldoende kritische opstelling ten aanzien van het strafdossier is dan ook van wezenlijk belang. Zo spreekt het voor zich dat de rechter niet zo doordrongen mag zijn van het strafdossier, dat hij bijvoorbeeld tijdens de ondervraging van de beklaagde enkel zou nagaan of hij geen elementen opwerpt die indruisen tegen de elementen van het strafdossier. ${ }^{246}$

Wanneer een rechter ambtshalve bepaalde initiatieven neemt, los van de houding die de andere procesdeelnemers of partijen innemen, wordt gesproken van een actieve rechter. ${ }^{247}$ De term actieve rechter wordt dan gebruikt tegenover de passieve of lijdelijke rechter. Het actief optreden van een rechter is niet noodzakelijk strijdig met het onpartijdigheidsbeginsel, maar dat legt wel grenzen op aan wat toegelaten is aan de actieve rechter. ${ }^{248}$ Het onpartijdigheidsbeginsel is dan ook een van de meest vermelde principiële bezwaren die klassiek worden aangevoerd tegen een actieve rol van de rechter. ${ }^{249}$ Volgens Kuty bijvoorbeeld, mag de rechter in beginsel niet zelf op zoek gaan naar bewijsmiddelen ten laste en moet hij, als het strafdossier onvoldoende elementen bevat om een veroordeling te schragen, beslissen tot vrijspraak. ${ }^{250}$ Anders zou de rechter dreigen eerder een onderzoeker dan een rechter te worden en zou hij afwijken van de bewijslastregels en daarmee een schijn van partijdigheid opwekken bij de andere partijen. De Wolf daarentegen komt tot het besluit dat het argument ontleend aan het onpartijdigheidsbeginsel niet op overtuigende wijze tot de conclusie leidt dat enkel een passieve rol van de rechter toelaatbaar is, maar dat

245 B. De Smet, 'Het onmiddellijkheidsbeginsel in het strafproces: een anachronisme of een waarborg voor een kwalitatief goede rechtspleging?', RW I996-97, 76.

246 Zie in die zin S. Sasserath, 'Procédure accusatoire et procédure inquisitoriale', Rev.sc.crim. I952, $5 \mathrm{I}$.

247 D. De Wolf, De rol van de rechter bij de waarheidsvinding in de correctionele procedure. Een rechtsvergelijkend onderzoek naar Belgisch, Frans en Nederlands recht, Kortrijk, UGA, 20II, nr. I2, 36.

248 Zie in die bewoordingen Cass. 28 februari 2008, RW 2008-09, 237, met noot A. Vandeplas en NJW 2008, 258, met noot N. Peeters.

249 Zie hierover uitgebreid D. De Wolf, De rol van de rechter bij de waarheidsvinding in de correctionele procedure. Een rechtsvergelijkend onderzoek naar Belgisch, Frans en Nederlands recht, Kortrijk, UGA, 20II, nrs. 4II-4I7, 495-504.

250 F. Kuty, L'impartialité du juge en procédure pénale. De la confiance décrétée à la confiance justifiée, Brussel, Larcier, 2005, 442. 
er wel behoefte is aan richtlijnen over wat de rechter wel en niet mag doen. ${ }^{25 \mathrm{I}} \mathrm{Hij}$ besluit verder dat de actieve rol van de rechter in de correctionele procedure versterkt dient te worden en stelt in dat verband onder meer voor om hem toe te laten, indien dat nodig is om de waarheid aan het licht te brengen, een van de leden van de rechtbank te gelasten met een aanvullend onderzoek, waarbij het bijvoorbeeld mogelijk zou zijn om een plaatsbezoek of een huiszoeking te verrichten..$^{252}$ Ook anderen hebben trouwens reeds gepleit voor meer procestijd voor het onderzoek ten gronde, ${ }^{253}$ of zelfs om het zwaartepunt volledig te verleggen naar de bodemrechter, die dan alle bijkomende onderzoekshandelingen zou moeten kunnen bevelen die hij nodig acht, zoals huiszoekingen, inbeslagnemingen of onderzoeken aan het lichaam. ${ }^{254}$ Het spreekt voor zich dat dergelijke voorstellen in elk geval slechts kunnen worden uitgewerkt in een globale en doortastende hervorming van het strafprocesrecht, waarbij de taak van de strafrechter duidelijk zou moeten worden omlijnd en waarbij er bovendien over gewaakt zou moeten worden dat de subtiele grens tussen wat wel en niet verenigbaar is met de rol van de rechter in het licht van het onpartijdigheidsbeginsel, niet wordt overschreden. Enige bedenkingen hieromtrent zijn misschien toch reeds op hun plaats. Met het voorstel om meer procestijd toe te bedelen aan het onderzoek ten gronde is op zich niets mis. Wanneer bijvoorbeeld getuigen worden gehoord tijdens de behandeling ten gronde, komt dat de tegenspraak ten goede, wat ook enigszins bijdraagt aan de neutraliteit van de strafrechter. Maar daarmee wordt niet afgeweken van het principe dat de bewijslevering in beginsel door de partijen gebeurt en dus, wat het belastend bewijsmateriaal betreft, door het openbaar ministerie en de burgerlijke partij. De rechter heeft derhalve nog steeds de rol van neutrale arbiter die te oordelen heeft over de aan hem voorgelegde bewijsmiddelen, waarvan er misschien meer dan nu het geval is ter zitting zouden worden gepresenteerd. Dat betekent niet dat de strafrechter helemaal passief zou zijn, omdat op het voormelde uitgangspunt een belangrijk correctief bestaat. In het Belgische systeem beschikt de strafrechter immers over een recht van initiatief om bewijzen te verzamelen ${ }^{255}$ en kan hij bijvoorbeeld inlichtingen vragen aan het openbaar ministerie, een deskundige aanstellen, getuigen horen ter zitting en de beklaagde verhoren, een plaatsbezoek bevelen en verrichten ${ }^{25}$ en andere aanvullende onderzoeksdaden suggereren. ${ }^{257}$ Het openbaar ministerie staat dan in voor de uitvoering van die aanvullende

$25 \mathrm{I}$ D. De Wolf, De rol van de rechter bij de waarheidsvinding in de correctionele procedure. Een rechtsvergelijkend onderzoek naar Belgisch, Frans en Nederlands recht, Kortrijk, UGA, 20II, nr. 4I7, 504.

252 D. De Wolf, De rol van de rechter bij de waarheidsvinding in de correctionele procedure. Een rechtsvergelijkend onderzoek naar Belgisch, Frans en Nederlands recht, Kortrijk, UGA, 201 I, nrs. 447-453, 54I-547.

253 Ch. Van den Wyngaert, 'De bijdrage van de internationale straftribunalen tot de ontwikkeling van het straf(proces)recht vanuit internationaal en Belgisch perspectief', in X., Strafrecht en strafprocesrecht. XXXIIe Postuniversitaire Cyclus Willy Delva, Mechelen, Kluwer, 2006, nr. 20, 563.

254 Y. Liégeois, 'De onvermijdelijke evolutie van het strafprocesrecht', in F. Deruyck, M. De Swaef, J. Rozie, M. Rozie, Ph. Traest en R. Verstraeten (eds.), De wet voorbij. Liber Amicorum Luc Huybrechts, Antwerpen, Intersentia, 20I0, 257.

255 Zie Cass. 26 mei 1999, Arr.Cass. I999, 728 en JT 1999, 622. Er bestaat echter geen verplichting voor de rechter om het gebrek aan bewijzen te verhelpen door aanvullend onderzoek te bevelen (Cass. 26 september 200I, Arr.Cass. 200I, I544).

256 Voor zover dit gebeurt in openbare plaatsen of met toestemming van de bewoner.

257 Dit alles uiteraard binnen de perken van zijn saisine. 
onderzoeksdaden, zonder dat de rechter evenwel bevelen kan geven aan het openbaar ministerie ${ }^{258}$ of rechtstreeks aan de politie. ${ }^{259}$ De rechter kan binnen die grenzen actief op zoek gaan naar de waarheid en aldus het strafproces enigszins sturen, zodat hij meer is dan een loutere arbiter, ${ }^{260}$ maar zonder dat dit gevolgen heeft voor zijn neutrale positie als beslisser over het strafproces. Anders wordt het evenwel wanneer de rechter de bevoegdheid krijgt om zelf allerlei verregaande onderzoeksmaatregelen (zoals huiszoekingen of inbeslagnemingen) te bevelen en zelfs te doen uitvoeren door een van de leden van de rechtbank, zoals voorgesteld wordt door De Wolf. Dat kan de neutrale positie van de rechter wel aantasten, omdat hij daardoor ook als het ware onderzoeker wordt. Dat lijkt geen wenselijke evolutie te zijn. Vooreerst zou het aanleiding kunnen geven tot heel wat discussies over het vereiste van onpartijdigheid, omdat ook in de visie van het EHRM het uitvoerig gebruik maken van onderzoeksbevoegdheden de onpartijdigheid van de rechter kan aantasten. ${ }^{26 r}$ Omdat de grens tussen wat dan precies wel en niet kan te onduidelijk is en eigenlijk zelfs een feitelijke beoordeling van de zaak vergt, ontstaat aldus het risico dat in vele zaken een schending van artikel 6.I EVRM zou worden opgeworpen. Bovendien zou de bevoegdheid voor de vonnisrechter om dwangmaatregelen zoals een huiszoeking te bevelen, vooral in het nadeel spelen van de verdediging, omdat daardoor nog actief gezocht kan worden naar bewijselementen à charge wanneer de door het openbaar ministerie aangevoerde elementen niet lijken te volstaan. Men kan zich afvragen of dat nog wel tot de taak van de rechter behoort. Om de onpartijdigheid van de strafrechter te vrijwaren, lijkt het beter dat het initiatief om verregaande onderzoeksmaatregelen uit te voeren of te doen uitvoeren, bij het openbaar ministerie of desgevallend de onderzoeksrechter blijft. ${ }^{262}$

De rol van de media

Het hoeft geen betoog dat strafzaken op vrij veel media-aandacht kunnen rekenen, zeker wanneer het om ernstige feiten gaat. Daardoor ontstaat geregeld de situatie dat er reeds een debat ontstaat bij de publieke opinie en in de media over een welbepaald feit of over een welbepaalde dader, terwijl over dat feit en vooral over de persoon die ervan verdacht wordt dat feit te hebben gepleegd, nog geoordeeld moet worden door een strafrechter. In zaken waarin de media uitgebreid verslag hebben gedaan voorafgaand en tijdens het proces, wordt dan ook soms geopperd dat de rechters die

258 Zie bijvoorbeeld Cass. 27 april I999, Arr.Cass. I999, nr. 24I en Cass. 30 oktober 200I, Arr.Cass. 200I, I8I5 en T.Strafr. 2002, I98.

259 Arbh. Gent 20 oktober 1972, RW I972-73, I679.

260 Zie J. De Codt, 'Preuves criminalistiques et vérité judiciaire', JT 2005, 205.

26I Zie supra over de cumulatie van het ambt van onderzoeksrechter en rechter ten gronde.

262 Zo kan bijvoorbeeld verwezen worden naar het feit dat de vonnisrechter in het kader van een bijzonder onderzoek naar de vermogensvoordelen onder meer een telefoontap kan bevelen, maar alleen op vordering van het openbaar ministerie (art. 524bis, \$5 Sv). Dat lijkt een veel gezondere situatie te zijn dan wanneer de strafrechter, die nadien mogelijk nog zal moeten beslissen over een vordering tot verbeurdverklaring, zelf het initiatief zou kunnen nemen om een telefoontap op te starten, ook al heeft hij op dat ogenblik al uitspraak gedaan over de schuld van de beklaagde. 
erover moeten oordelen, dat niet meer onbevangen zouden kunnen doen. Zo erkent het EHRM dat in bepaalde gevallen een verregaande perscampagne van dien aard kan zijn dat het eerlijk karakter van het proces in het gedrang wordt gebracht door de beïnvloeding van de publieke opinie en onrechtstreeks ook (bewust of onbewust) van een jury of zelfs van de beroepsrechters. ${ }^{263}$ Daarom is het van belang dat wanneer de pers bericht over lopende strafzaken, zij dient te vermijden dat door haar commentaren een persoon veroordeeld wordt door de publieke opinie vóór elk proces. ${ }^{264}$ Dat heeft echter niet veel meer waarde dan een aanbeveling, omdat het in de praktijk niet tot sancties aanleiding geeft. ${ }^{265}$ Het Hof van Cassatie stelt immers dat de rechter vermoed wordt onpartijdig te zijn tot het bewijs van het tegendeel en dat de professionaliteit waarmee een rechter zijn taak uitoefent, impliceert dat de rechter kan omgaan met de druk van de media. ${ }^{266}$ In de zaak Dutroux was de vraag naar het gevolg van de mediacampagne ook aan de orde en besliste het Hof van Cassatie dat noch uit een mediacampagne die nog nooit eerder was gezien, noch uit verklaringen uitgaande van de overheid, noch uit de reproductie in de pers van sommige passages uit het strafdossier of uit een opiniepeiling kon worden afgeleid dat de jury of de magistraten waaruit het hof van assisen bestond niet onpartijdig zouden zijn geweest of het vermoeden van onschuld zouden hebben miskend. ${ }^{267}$ Ook in de zaak Van Temsche, over een jonge man die een jachtgeweer had gekocht en daarna op moordtocht rondtrok in Antwerpen, werd een middel afgewezen dat betrekking had op deze problematiek. Het Hof van Cassatie preciseerde dat de onpartijdigheid waarvan de rechter blijk moet geven, in de regel bereikt is door de houding van die rechter bij de behandeling van de zaak. ${ }^{268}$ Meer bepaald moet de rechter, zo verduidelijkte het Hof, vooraleer hij over de zaak uitspraak doet, erover waken dat hij geen standpunten inneemt waardoor hij laat merken dat hij reeds een mening heeft over de hem voorgelegde geschilpunten. Dat berichtgeving in de pers ook de rechter en de jury van het hof van assisen kan bereiken, houdt daarom volgens het Hof niet in dat daardoor een schijn van partijdigheid ontstaat, omdat die berichtgeving het recht op een eerlijk proces en het recht van verdediging van die beschuldigde voor het bevoegde gerecht niet onherstelbaar in het gedrang brengt. Het Hof wees er verder op dat de beschuldigde in openbare terechtzitting alle hem nadelige gegevens, ook deze die de media hebben bekendgemaakt, kan tegenspreken en ook de

263 Zie bijvoorbeeld EHRM II december 2003, Claes t. België, beslissing over de ontvankelijkheid, nr. $46825, \$ 5$. Zie ook B. Tavernier, 'La prescription d'innocence et la médiatisation de la justice: une cohabitation précaire', Rev.dr.pén. 2003, 33-85 en F. Tulkens, 'La présomption d'innocence. Les développements récents de la jurisprudence de la Cour européenne des droits de l'homme', in A. Alen, E. Dirix, W. Pintens en P. Senaeve (eds.), Feestbundel voor Hugo Vandenberghe, Brugge, Die Keure, 2007, 305-317.

264 F. Kuty, Justice pénale et proces équitable, II, Brussel, Larcier, 2006, nrs. I6Io en volgende en de rechtspraak aldaar geciteerd.

265 Zie hierover R. Verstraeten, 'Recht en mediatisering', in De Orde van Advocaten te Antwerpen (ed.), Over mediatisering van justitie? Referatenboek congres 16 oktober 2008, Brussel, Larcier, 2009, nrs. 2I-27, II-I5.

266 Cass. I6 december I998, RW I998-99, I34I.

267 Cass. I5 december 2004, Arr.Cass. 2004, 2024, NJW 2005, 766, NC 2006, 44 en Rev.dr.pén. 2005, 33I.

268 Cass. I9 februari 2008, NJW 2008, 256, met noot E. Brewaeys, NC 2008, I44 en T.Strafr. 2008 , IIo. 
voor hem gunstige gegevens aan de rechters en de juryleden kan voorleggen. Het Hof besloot dat een dergelijke behandeling van de zaak een eventuele aanvankelijke beïnvloeding van de openbare opinie en, bijgevolg, van de leden van de jury door berichtgeving in de media ongedaan kan maken. Het is niet zeker of dat standpunt eigenlijk wel strookt met de geest van het vereiste van onpartijdigheid, dat er toch toe lijkt te strekken dat de strafrechter ook bij de aanvang van het proces niet vooringenomen of bevooroordeeld mag zijn. Men moet zich trouwens ernstig de vraag stellen hoe het te bewijzen of te controleren zou vallen dat, wanneer de beïnvloeding van de rechters bij de aanvang van het proces wel degelijk zou vaststaan (wat in het voormelde arrest in het midden werd gelaten), die beïnvloeding uiteindelijk ongedaan werd gemaakt door het proces ten gronde en dus niet heeft gespeeld bij de oordeelsvorming. Dat is uiteraard, gelet op het geheim der beraadslaging, onmogelijk aan te tonen voor degene die veroordeeld wordt, tenzij uit de motivering van de beslissing zou blijken dat de perscampagne de vorming van de opinie van de rechters zou hebben beïnvloed.

Omdat het over de schreef gaan de facto onbestraft blijft, is overdreven media-aandacht in strafzaken een heikel punt. Onder het mom van het zogenaamde 'infotainment' worden de grenzen immers almaar verlegd en worden zelfs soms - zoals in de parachutemoord gebeurde - opiniepeilingen geopend met als onderwerp de schuld of onschuld van een beschuldigde die op dat ogenblik terechtstaat. Men kan zich afvragen of dat een goede zaak is, ook al is het een realiteit die moeilijk uit te roeien valt en die we dus onder ogen moeten zien. Toch kan een 'trial by media' bezwaarlijk worden gelijkgesteld met een 'fair trial'. ${ }^{269}$ Zeker wanneer het een volksjury betreft, is het gevaar niet ondenkbeeldig dat de mediaverslaggeving voorafgaand en tijdens het proces toch een zekere invloed kan hebben op de beoordeling van de zaak, al valt dat wel erg moeilijk te bewijzen. ${ }^{270}$ Het is in elk geval opvallend dat het EHRM ook reeds heeft aangehaald dat beroepsrechters, in tegenstelling tot een volksjury, kunnen bogen op een opleiding en op een ruime ervaring die hen toelaat om elke vorm van externe druk te weerstaan. ${ }^{271}$

Soms gebeurt het dat een politiek figuur zich bemoeit met een concrete strafzaak, bijvoorbeeld omdat die zaak op erg veel mediabelangstelling kan rekenen en men op die manier bij wijze van spreken wil meesurfen op de aandachtsgolf. Een treffend voorbeeld kan - alweer - worden geput uit de zaak Dutroux. Toen het Hof van Cassatie te beslissen had over het reeds vermelde 'spaghetti-incident', werd door bepaalde parlementsleden gesuggereerd dat het Hof best 'creatief' zou zijn bij de beoordeling

269 Zie bijvoorbeeld ook K.S.A. Ebeku, 'Revisiting the acquittal of Io policemen: issues of judicial independence, trial by media and fair trial in Cyprus', EJCCL \& CJ $2010, \mathrm{I}-42$.

270 Toch is het bewijzen ervan ook voor het EHRM vereist om een schending van het recht op een eerlijk proces te kunnen aannemen (zie EHRM I5 november 200I, Papon t. Frankrijk, beslissing over de ontvankelijkheid).

27 EHRM 5 december 2002, Craxi t. Italië, §IO4, NJB 2003, 282. 
van het verzoek tot wraking van de onderzoeksrechter. ${ }^{272}$ Het Hof liet zich echter niet vermurwen. Dergelijke uitlatingen zijn uiteraard uit den boze omdat ze een schijn van afhankelijkheid kunnen genereren. De beslissing van de rechter moet gesteund zijn op zijn librum arbitrium, zijn vrije oordeelsvorming. Daaruit volgt dat geen enkele instantie, en dus ook niet een politicus, voorschriften of zelfs maar aanbevelingen mag geven aan een rechter betreffende een zaak die bij hem aanhangig is. ${ }^{273}$ Zelfs de louter theoretische mogelijkheid daarvan moet onbestaande zijn. ${ }^{274}$

De volksjury

Het hof van assisen kent in België zowel voor- als tegenstanders. De discussie over het al dan niet afschaffen van het hof van assisen laait dan ook regelmatig op. ${ }^{275} \mathrm{De}$ vraag of deze instelling al dan niet behouden moet blijven, gaat uiteraard het bestek van dit preadvies te buiten. Wel kan erop gewezen worden dat, zoals hoger reeds aangehaald, het EHRM van oordeel is dat beroepsrechters meer dan een volksjury geacht kunnen worden te kunnen weerstaan aan gebeurlijke druk van buitenaf, zoals de druk van de media. In dat opzicht zou besloten kunnen worden dat er wat het recht op een onafhankelijke en onpartijdige rechter betreft meer waarborgen verbonden zijn aan een beoordeling door beroepsrechters dan het geval is bij een beoordeling door een volksjury, al lijken juryleden hun opdracht in de praktijk erg nauwgezet en gewetensvol ter harte te nemen.

\section{Slotbeschouwing}

Het belang van de neutraliteit van de strafrechter blijkt uit de vele instrumenten waarover het Belgische recht beschikt om de onpartijdigheid en de onafhankelijkheid van de rechter te waarborgen. Dat komt vooral de objectieve onpartijdigheid ten goede. Wat de subjectieve partijdigheid betreft, kunnen wetsbepalingen hoogstens de kans verkleinen maar kunnen ze niet uitsluiten dat er in individuele gevallen toch soms eens sprake kan zijn van partijdigheid of vooringenomenheid ten aanzien van een welbepaalde strafrechter in een welbepaalde zaak, wat ook blijkt uit de rechtspraak inzake wraking. Menselijke tussenkomst brengt nu eenmaal ook de mogelijkheid op menselijke fouten met zich. De wetgever doet er goed aan ook

272 Zie J. Messine, 'De quelques suites de l'affaire Dutroux sur le pouvoir judiciaire et sur l'indépendance des juges', in X., Liber Amicorum Henri-D. Bosly, Brussel, La Charte, 2009, 240.

273 Zie bijvoorbeeld EHRM 28 juni I984, Campbell \& Fell t. Verenigd Koninkrijk, Serie A, vol. 80, \$79.

274 K. Wagner, 'De onafhankelijkheid van de rechter naar Europees recht', in P. Van Orshoven, L.F.M. Verhey en K. Wagner, De onafhankelijkheid van de rechter, preadvies voor de Vereniging voor de Vergelijkende Studie van het Recht van België en Nederland, Deventer, Tjeenk Willink, 20oI, nr. 6,8 .

275 Zie over de evolutie in dit verband J. Van Meerbeeck, 'Une décennie mouvementée pour la cour d'assises', Rev.dr.pén. 20II, 392-408. Zie onder meer ook R. Verstraeten en L. Gyselaers, 'De wetvan 2I december 2009 tot hervorming van het Hof van assisen', in R. Verstraeten en F. Verbruggen, Straf- en strafprocesrecht, Brugge, Die Keure, 2010, 89-I24 en M. Fernandez-Bertier, 'La réforme de la cour d'assises: le législateur a encore raté le coche', Ann.dr.Louvain 20Io, afl. 2, 67-II7. 
bij toekomstige aanpassingen steeds oog te blijven hebben voor het vereiste van onafhankelijkheid en onpartijdigheid van de strafrechter. Dat geldt zeker wanneer het om drastische aanpassingen zou gaan, zoals het voorstel van sommigen om de strafrechter een meer actieve rol toe te bedelen en hem zelfs in de mogelijkheid te stellen om bepaalde aanvullende onderzoeken te gelasten of door een lid van de rechtbank zelf uit te laten voeren. Soms zijn beginselen zo evident, dat de wetgever ze al eens sneller uit het oog verliest. Het vereiste van onafhankelijkheid en onpartijdigheid van de rechter is echter te belangrijk om dat lot te ondergaan. 